\title{
LAS INJUSTAS DIFERENCIAS EXISTENTES EN LA LIBERTAD DE TESTAR DENTRO DEL TERRITORIO ESPAÑOL*
}

\author{
THE UNJUST DIFFERENCES \\ EXISTING TESTAR FREEDOM WITHIN \\ THE SPANISH TERRITORY
}

\author{
Alejandro Platero-Alcón $* *$ \\ Fecha de recepción: 17 de julio de 2016 \\ Fecha de aceptación: 15 de febrero de 2017 \\ Disponible en linea: 30 de noviembre de 2017
}

\section{Para citar este artículo/To cite this article}

\author{
Platero Alcón, Alejandro, Las injustas diferencias existentes en la libertad \\ de testar dentro del territorio, 135 Vniversitas, 283-324 (2017). http://dx.doi. \\ org/10.11144/Javeriana.vj135.idel \\ doi:10.11144/Javeriana.vj135.idel
}

Este trabajo se ha realizado en el marco del Programa Nacional de Formación de Profesorado Universitario dependiente del Ministerio de Educación, Cultura y Deporte del Gobierno de España.

** Investigador y docente (FPU) del área de derecho civil, Universidad de Extremadura, España. ORCID: 0000-0002-3318-6441. Licenciado en derecho y administración y dirección de empresas. Magíster en abogacía y magíster en investigación en ciencias sociales y jurídicas. Investigador del grupo de investigación de Estudios del Derecho de España, Portugal y América Latina, GIDEPA: Avenida de la Universidad s/n, 10003 Cáceres, España. Contacto: platero@unex.es 


\section{RESUMEN}

El presente trabajo tiene como objetivo el análisis de la institución de la legítima, la cual es concebida como una auténtica limitación de la libertad de testar en la mayoría de los ordenamientos jurídicos que la regulan. Este análisis constatará la desigualdad existente entre la regulación en el sistema de derecho común, contenida en el Código Civil español y la regulación de la legítima en los derechos forales. La competencia en materia de derecho civil no solo la ostenta el Estado, sino que esa competencia reside también en los regímenes forales, de tal suerte que la institución será objeto de análisis en Galicia, Navarra, Aragón, Cataluña, Islas Baleares y el País Vasco. Se prestará especial atención a la exposición de sus antecedentes históricos, el debate doctrinal sobre su naturaleza jurídica, y cómo no, las dos cuestiones fundamentales de cualquier sistema legitimario, es decir, determinar quién ostenta la condición de legitimario y qué cuota hereditaria ostenta.

Palabras clave: Legítima; legitimario; cuota; pars bonorum; usufructo viudal 


\section{ABSTRACT}

The present work aims to analyze the institution of legitimate, which is conceived as a real limitation of the freedom to make in most legal systems that regulate it. This analysis shall verify the inequality between the existing regulation in the system of common law, regulated in the Spanish Civil Code and regulation of legitimate existing in the leasehold Rights. Competition on civil law not only holds the state, but that power also resides in the leasehold regimes, so such that the institution will be analyzed in Galicia, Navarra, Aragon, Catalonia, the Balearic Islands and in the Basque country. Special attention exhibition of its historical background, the doctrinal debate on its legal nature, and of course, the two fundamental questions of any legitimario system, i.e., determine who has the status of heir will be paid and legitimizing share holds right.

Keywords: Legitimate heir; share; pars bonorum and usufruct dower.

\section{SUMARIO}

INTRODUCCIÓN.- I. LA REGULACIÓN DE LA LEGÍTIMA EN EL DERECHO COMÚN.A. Análisis del concepto y antecedentes históricos de la legítima.- B. Discusión sobre la naturaleza jurídica de la institución.- C. ¿Quiénes son los denominados herederos forzosos?- II. EL RÉGIMEN FORAL GALLEGO.- III. EL RÉGIMEN FORAL NAVARRO.- IV. El RÉGIMEN FORAL CATALÁN.- V. El RÉGIMEN FORAL ARAGONÉS.- VI. El RÉGIMEN FORAL BALEAR.- $A$. La regulación en las Islas de Mallorca y Menorca.- B. La regulación en las islas de Ibiza y Formentera.- VII. El RÉgIMen foral vasco.- A. Análisis del régimen general vasco.- B. Primera excepción del régimen Vasco: el fuero de Bizkaia.- C. Segunda excepción del régimen vasco: el fuero de Ayala.- Conclusiones.Bibliografía. 


\section{INTRODUCCIÓN}

El presente artículo parte del estudio de la institución de la legítima, una de las cuestiones más debatidas en la disciplina del derecho civil. Como se expondrá en los siguientes epígrafes, la legítima se configura como un límite a la libertad del testador para poder dejar por testamento, los bienes que estime conveniente, a los sujetos que él considere idóneos para sucederlo.

La justificación del tema de la presente obra radica en los diferentes límites a libertad de testar que se encuentran en España, que provocan distintas restricciones en función de la residencia del testador dentro del territorio español. Para el examen de estos regímenes distintos, se expondrá en primer lugar, el sistema legitimario que aparece regulado en la normativa de aplicación nacional, para exponer en segundo lugar, la regulación desigual que aparece en aquellos territorios que tienen competencia para regular dicha institución.

En efecto, el punto de partida del presente trabajo será determinar el alcance y naturaleza de la legítima vigente en el denominado derecho común, es decir, aquellos territorios donde no resulta de aplicación ningún derecho foral. Serán objetos de exposición sus rasgos fundamentales, partiendo de la exposición de sus antecedentes históricos, el debate doctrinal sobre su naturaleza jurídica, y cómo no, las dos cuestiones fundamentales de cualquier sistema legitimario, es decir, determinar quién ostenta la condición de legitimario y a qué cuota legitimaria ostenta derecho.

Como se establecía anteriormente, no solo se realizarán referencias al sistema de derecho común del territorio español, sino que también, serán objeto de análisis, todos y cada uno de los aspectos descritos anteriormente, en aquellas comunidades autónomas con competencia en materia de derecho civil, que han legislado la cuestión. Así, se hará mención al régimen gallego, al navarro, al aragonés, al catalán, al balear y, cómo no, al régimen vigente en la comunidad autónoma del País Vasco. Además, en la exposición de cada uno de los regímenes expresados, se realizarán referencias y comparaciones con el sistema establecido en el derecho común, comparaciones realizadas siempre siguiendo un orden establecido, con la intención fundamental, de no perder y aclarar las 
ideas del lector, aunque con la intención de poner de manifiesto la desigualdad existente entre las diferentes regulaciones. Este orden comenzará con la exposición de los antecedentes históricos de la institución, continuará con la exposición de la naturaleza jurídica de esta, para terminar con los dos aspectos fundamentales expuestos anteriormente, determinar quién ostenta la condición de legitimario y a qué cuota legitimaria ostenta derecho.

En último lugar, se expondrá una serie de conclusiones del presente trabajo que pretende sintetizar sus ideas fundamentales y, cómo no, aportar una valoración personal acerca de la tan controvertida institución.

\section{LA REGULACIÓN DE LA LEGÍTIMA EN EL DERECHO COMÚN}

La institución de la legítima es uno de los grandes caballos de batalla de la disciplina del derecho civil y, más concretamente, en la problemática del derecho de sucesiones. Una vez acaecida la muerte de un ser vivo, se produce la apertura de su sucesión hereditaria, cuyo fundamento tradicional como establece José María Castán-Vázquez, "es la necesidad de perpetuar patrimonios más allá de los límites de la vida humana"1, o en palabras más simples de otro autor "la sucesión hereditaria no es otra cosa que el modo de continuar y perpetuar la propiedad individual del causante"2.

\section{A. Análisis del concepto y antecedentes históricos de la legítima}

La legítima desplegará sus efectos en el fenómeno sucesorio que se afecta especialmente en caso de que se produzca una sucesión testada $^{3}$, ya que la sucesión abintestato $^{4}$ tiene sus propias reglas de

1 José María Castán-VÁzquez, Notas sobre la sucesión contractual en el derecho español, 17 Anuario de Derecho Civil, 2, 367-382, 370 (1964). Disponible en: https:/www.boe.es/publicaciones/ anuarios_derecho/articulo.php?id=ANU-C-1964-20036700382, https://goo.gl/onXPBk

2 María Paz Pous de la Flor, Partición de la herencia, 21 (Editorial Juruá, Lisboa, 2016).

3 La sucesión testamentaria o testada encuentra su fundamento en el artículo 658 del Código Civil, donde se establece que la sucesión será testamentaria cuando "se defiere por la voluntad del hombre manifestada en testamento". España, Real Decreto de 24 de julio de 1889 por el que se publica el Código Civil, 206 Boletín Oficial del Estado, BOE, 25 de julio de 1889. Disponible en: https://www. boe.es/buscar/act.php?id=BOE-A-1889-4763

4 Tiene su fundamento en el artículo 913 del Código Civil, al establecer que "a falta de herederos 
división. El artículo 806 del Código Civil (en adelante, CC) establece: "la legítima es la porción de bienes de que el testador no puede disponer por haberla reservado la ley a determinados herederos, llamados por esto herederos forzosos"5. En vista del concepto aportado legalmente, se puede extraer que el testador no puede disponer de todo su patrimonio como desee en su testamento, sino que ostenta una limitación, denominada legítima.

El concepto de legítima no viene únicamente del precepto citado con anterioridad, sino que grandes autores en la disciplina del Derecho Civil también han querido aportar el suyo. En efecto, la legítima puede ser entendida como "la porción o cuota a que tienen derecho los parientes en línea recta y el cónyuge de cualquier persona, en el patrimonio de esta, a percibir a partir de su muerte, si no se recibió en vida" . En sentido similar se pronuncia el profesor Carlos Lasarte-Álvarez, al considerar que "la existencia de la legítima implica una restricción de la libertad de testar testamentaria, que se trata de una imposición establecida por el legislador al causante, en beneficio de las personas más cercanas o allegadas a él y que forman parte, en consecuencia, de su círculo familiar"?.

Esta restricción en la libertad de testar ha ocasionado enormes debates $^{8}$ y críticas en la disciplina. Algunos autores están en total desacuerdo con la misma, considerando que "la actual regulación de la legítima del Código Civil no tiene cabida en una concepción de la persona y familia propias del siglo XXI, que nada tienen que ver con la que existía en el tiempo de la Codificación, por lo que, consideramos que la legítima debería desaparecer por completo, siendo desterrada de las leyes, dejando a salvo, eso sí, la protección de los menores e incapacitados, única justificación que encontramos

testamentarios, la Ley defiere la herencia a los parientes del difunto, al viudo o viuda y al Estado".

5 España, Real Decreto de 24 de julio de 1889 por el que se publica el Código Civil, 206 Boletín Oficial del Estado, BOE, 25 de julio de 1889. Disponible en: https://www.boe.es/buscar/act.php?id=BOEA-1889-4763

6 José Luis Lacruz-Berdejo, Elementos de derecho civil, V, Sucesiones, 309 (Editorial Dykinson, Madrid, 2009).

7 Carlos Lasarte-Álvarez, Principios de derecho civil VII, Derecho de sucesiones, 163 (10 ed., Editorial Marcial Pons, Madrid, 2015).

8 No solo hay posiciones en contra o favor de la legítima, sino también numerosos estudios que proponen una serie de cambios en su configuración. Véase, por ejemplo, la obra de Aurelio BarRioGallardo, Atemperar la rigidez de la legítima, 21 Revista Doctrinal Aranzadi Civil-Mercantil, 1-25 (2007). O la obra de ANTONI VAQUER-AlOY, Reflexiones sobre una eventual reforma de la legítima, 3 InDret, 1-25 (julio de 2007). Disponible en: http://www.indret.com/es/?ed=32, http://www.indret. com/pdf/457_es.pdf 
hoy a la institución"9. También, cómo no, hay autores que justifican el origen y la finalidad de la legítima, de suerte tal que "somos de la idea de que lo que el legislador quiso asegurar incorporando el sistema de legítima, es acertado si su fin es el de garantizar la continuidad de la familia respecto de quienes están en potestad del padre de familia, es decir, de quienes aún no están en condiciones de garantizar su independencia económica"10.

Antes de desgranar los principales caracteres de la institución, es preciso hacer una breve referencia a los orígenes de la misma, ya que no es ni mucho menos una figura que apareció con el Código Civil. En efecto, ya en el derecho romano, a partir del siglo II se empieza a entender que los hijos y parientes cercanos no pueden apartarse de la sucesión; en la época de Justiniano I, el Grande (482-565), se estableció que si los hijos del fallecido eran cuatro o menos, recibirían un tercio de sus bienes, pero si fueran un número mayor, recibirían la mitad del caudal hereditario; en el derecho germánico, en cambio, se partía de una concepción idealizada de familia, considerándose que todo el patrimonio del causante debía repartirse entre sus descendientes. Históricamente, en el derecho español ${ }^{11}$, debe destacarse la aportación del derecho visigodo, concretamente la ley Dum inlicita, del siglo VII, que reguló la cuestión, estableciendo que los hijos tenían derecho a cuatro quintas partes del patrimonio de sus padres, enfoque que continuó con las denominadas Leyes de Toro, de 1505, que únicamente introdujeron una modificación, la introducción de la cuota de dos tercios de la legítima de los ascendientes.

9 Ángel Acedo-Penco, Derecho de sucesiones. El testamento y la herencia, 155 (Editorial Dykinson, Madrid, 2014).

10 Richard Aguilar-Díaz, De la libertad para testar con la legítima, 6 La Ley Derecho de Familia: Revista Jurídica sobre Familia y Menores, 75-84, 79 (2015). Disponible en: https://goo.gl/nlic45

11 Un estudio detallado sobre la regulación de la legítima antes del surgimiento del Código Civil en España, en la obra de Manuel Peña-Bernaldo de Quirós, La naturaleza de la legítima, 38 Anuario de Derecho Civil, 4, 849-908 (1985). Disponible en: https://www.boe.es/publicaciones/anuarios_derecho/abrir_pdf.php?id=ANU-C-198540084900908_ANUARIO_DE_DERECHO_CIVIL_La_naturaleza_de_la_leg\%EDtima 


\section{B. Discusión sobre la naturaleza jurídica de la institución}

Una vez expuesto el concepto de legítima, y tras haber realizado una referencia a la restricción de la libertad de testar que supone dicha institución y a su carácter histórico, es el momento de analizar sus principales características contenidas en el Código Civil y, por ende, resultantes de la aplicación en el territorio común, para poder ser comparadas con las características existentes en el derecho foral ${ }^{12}$, ya que este es el verdadero núcleo del presente trabajo.

En este momento, es preciso recordar el contenido del artículo 806 de CC citado con anterioridad. Así, la legítima es la porción de bienes de que el testador no puede disponer por haberla reservado la ley a determinados herederos, llamados por esto herederos forzosos. De este concepto dos cuestiones llaman especialmente la atención: la referencia a la legítima como una porción de bienes, y en segundo lugar, la mención a los denominados herederos forzosos.

En relación con la alusión a la legítima como una porción de bienes, se debe poner de manifiesto que esta mención se refiere a su naturaleza jurídica. En efecto, la legítima se suele considerar como una porción de bienes, o pars bonorum, del haber hereditario, o "el que debiera haber sido el activo patrimonial si el causante no hubiera hecho donaciones en vida, siendo en síntesis, parte del haber hereditario"13, y además, es preciso denotar que la expresión porción de bienes "no puede significar que el legislador fije y señale ciertos bienes o categorías de bienes que han de quedar reservados. Sería sencillamente imposible, pues la generalidad del fenómeno sucesorio lo impide (...) debe de ser entendida en cambio, como una parte o cuota de carácter general, aplicable a cualesquiera bienes hereditarios"14. Para terminar con la referencia a la naturaleza jurí-

12 El conjunto de normas que se aplican solo a ciertas regiones, constituye el denominado Derecho Foral. Se utiliza la expresión Derecho Foral y no Derechos Forales, siguiendo lo establecido por MANUEL Albaladejo-García, Derecho Civil, I, Introducción y parte general (17 a ed., Editorial Edisofer, Madrid, 2006), cuando establece que "se habla usualmente de Derecho Foral para referirse bien a todos los Derechos Forales en su conjunto, buen a una o varias normas que no sean de Derecho común".

13 Pedro de Pablo-Contreras, Miguel Ángel Pérez-Álvarez, Carlos Martínez de Aguirre-Aldaz \& Sergio Cámara-Lapuente, Curso de Derecho civil V, Derecho de Sucesiones, 280 (Editorial Colex, Madrid, 2013).

14 Carlos Lasarte-Álvarez, Principios de derecho civil VII, Derecho de sucesiones, 164 (10 ed., Editorial Marcial Pons, Madrid, 2015). 
dica de la legítima ${ }^{15}$, y teniendo en cuenta que el objetivo del trabajo no es un análisis exhaustivo de todos los aspectos de la figura, sino una exposición de sus principales rasgos en el derecho común y en el derecho foral, se debe hacer mención a que la jurisprudencia ha rechazado desde antiguo la consideración de la legítima como pars valoris, o un derecho de crédito ${ }^{16}$, al reafirmar su carácter de porción de bienes.

\section{C. ¿Quiénes son los denominados herederos forzosos?}

La segunda cuestión que debe ser destacada del artículo 806 CC es la referencia a los herederos forzosos. En efecto, el Código Civil considera que los legitimarios, es decir, los sujetos que tienen derecho a esa porción de bienes reservada por imperativo legal, son herederos forzosos. Pues bien, esta denominación tampoco está exenta de polémica, ya que en palabras de algún autor autorizado, "no es correcto llamarles herederos forzosos porque la legítima, a veces, se recibe en vida del causante, sin necesidad de que exista herencia de por medio, como ocurre cuando dicha porción del patrimonio se recibe por donación, o también, puede dejarse a los legitimarios por vía de legado" 17 . En el mismo sentido se pronuncia José Luis Lacruz-Berdejo, al considerar que "si la legítima puede hacerse efectiva por cualquier título, puede ocurrir que haya sido satisfecha en vida del causante, mediante donaciones (...) en tal

15 La naturaleza jurídica de la legítima es una de las cuestiones más tratadas por la disciplina civilista desde antiguo. Uno de los autores que más han contribuido al estudio de la naturaleza jurídica de la institución es JuAN B. VALLET DE GOYTISOLO, Notas críticas acerca de la pretendida distinción entre cuota de reserva y cuota de legítima, 18 Anuario de Derecho Civil, 1, 3-140 (1965). Disponible en: https://www.boe.es/publicaciones/anuarios_derecho/abrir_pdf.php?id=ANU-C-1965-10000300140. Es necesario destacar por su importancia la obra de GuILlermo García-VALDECASAs, La legítima como cuota hereditaria y como cuota de valor, XLVII Revista de Derecho Privado, 957-977 (1963). Disponible en: http://goo.gl/ZpwPPt

16 España, Tribunal Supremo de Justicia, Sala Civil, Sentencia, 8 de marzo de 1989, magistrado ponente José Luis Albácar-López. Disponible en: http://supremo.vlex.es/vid/-76213414. España, Tribunal Supremo de Justicia, Sala Civil, Sentencia, 26 de abril de 1997, magistrado ponente Pedro González-Poveda. Disponible en: http://goo.gl/AtLdWn

17 Ángel Acedo-Penco, Derecho de sucesiones. El testamento y la herencia, 157 (Editorial Dykinson, Madrid, 2014). En el mismo sentido se pronuncia Antonio RomÁn-García, Derecho de sucesiones, instituciones de derecho civil español VII, 205 (Editorial McGraw-Hill, Madrid, 1999). 
caso, el legitimario no puede tener ninguna pretensión sobre los bienes que dejó el causante, pues su legítima le ha sido ya pagada"18.

La descripción de los herederos forzosos aparece en el artículo $807 \mathrm{CC}$, que establece que "son herederos forzosos: 1. Los hijos y descendientes respecto de sus padres y ascendientes. 2. A falta de los anteriores, los padres y ascendientes respecto de sus hijos y descendientes. 3. El viudo o viuda en la forma y medida que establece este Código".

La legítima de los descendientes aparece regulada en el artículo $808 \mathrm{CC}$, que establece que "constituyen la legítima de los hijos y descendientes las dos terceras partes del haber hereditario del padre y de la madre", es decir, un $66,66 \%$ del mismo. Cabe la posibilidad de que un progenitor desherede a su descendiente por la concurrencia de los motivos específicos previstos en el artículo 853 del $\mathrm{CC}^{19}$, que se suman a las causas de suceder por indignidad generales establecidas en el artículo $756 \mathrm{CC}^{20}$ y se produzca en estos casos el efecto previsto en el artículo $857 \mathrm{CC}$, "los hijos o descendientes del desheredado ocuparán su lugar y conservarán los derechos de herederos forzosos respecto a la legítima". Ahora bien, este traspaso de posiciones ha sido debatido por la doctrina;

18 José Luis Lacruz-Berdejo, Elementos de derecho civil, V, Sucesiones, 322 (Editorial Dykinson, Madrid, 2009).

19 Artículo 853 del Código Civil: Serán también justas causas para desheredar a los hijos y descendientes, además de las señaladas en el artículo 756 con los números 2, 3, 5 y 6, las siguientes: 1 . Haber negado, sin motivo legítimo, los alimentos al padre o ascendiente que le deshereda. 2. Haberle maltratado de obra o injuriado gravemente de palabra.

20 Artículo 756 del Código Civil: Son incapaces de suceder por causa de indignidad: 1. El que fuera condenado por sentencia firme por haber atentado contra la vida, o a pena grave por haber causado lesiones o por haber ejercido habitualmente violencia física o psíquica en el ámbito familiar al causante, su cónyuge, persona a la que esté unida por análoga relación de afectividad o alguno de sus descendientes o ascendientes. 2. El que fuera condenado por sentencia firme por delitos contra la libertad, la integridad moral y la libertad e indemnidad sexual, si el ofendido es el causante, su cónyuge, la persona a la que esté unida por análoga relación de afectividad o alguno de sus descendientes o ascendientes. Asimismo el condenado por sentencia firme a pena grave por haber cometido un delito contra los derechos y deberes familiares respecto de la herencia de la persona agraviada.

También el privado por resolución firme de la patria potestad, o removido del ejercicio de la tutela o acogimiento familiar de un menor o persona con la capacidad modificada judicialmente por causa que le sea imputable, respecto de la herencia del mismo. 3. El que hubiese acusado al causante de delito para el que la ley señala pena grave, si es condenado por denuncia falsa. 4 . El heredero mayor de edad que, sabedor de la muerte violenta del testador, no la hubiese denunciado dentro de un mes a la justicia cuando esta no hubiera procedido ya de oficio. 5. El que, con amenaza, fraude o violencia, obligare al testador a hacer testamento o a cambiarlo. 6 . El que por iguales medios impidiere a otro hacer testamento, o revocar el que tuviese hecho, o suplantare, ocultare o alterare otro posterior. 7. Tratándose de la sucesión de una persona con discapacidad, las personas con derecho a la herencia que no le hubieren prestado las atenciones debidas, entendiendo por tales las reguladas en los artículos 142 y 146 del Código Civil. 
se escuchan opiniones que consideran "conviene aclarar que los hijos ocupan la porción del padre desheredado pero no adquieren la cualidad de legitimarios, sino que son destinatarios de una porción que ha quedado vacante a consecuencia de la desheredación de su progenitor. En la práctica, dudo que tengan que ser llamados a la herencia para estar presentes en la partición de la herencia y dar su consentimiento, como intervención que es típica del legitimario" 21. En el caso de que el testador no incluya a alguno de sus hijos en su testamento, sin que medie ninguna causa justa de desheredación, entra en escena la figura de la preterición ${ }^{22}$, que en el caso de que sea intencional, tiene como efecto la no perjudicación de los derechos legitimarios del heredero forzoso ${ }^{23}$.

La legítima de los ascendientes aparece regulada en el artículo $809 \mathrm{CC}$, que establece que "constituye la legítima de los padres o ascendientes la mitad del haber hereditario de los hijos y descendientes salvo el caso en que concurrieren con el cónyuge viudo del descendiente causante, en cuyo supuesto será de una tercera parte de la herencia". De este precepto se debe destacar en primer lugar que los padres o ascendientes solo heredarán en caso de que no haya hijos o descendientes, y en segundo lugar, la crítica realizada por autores autorizados en la disciplina, ya que la consideran una figura arcaica y creadora de problemas, de suerte tal que "la legítima de los padres y ascendientes tiene una cuantía que también puede ser considerada exagerada. Pensemos en un ejemplo que se da en la realidad social. El matrimonio sin hijos en que uno de los cónyuges fallece: la tercera parte de sus bienes la percibirán los padres como legítima y si el cónyuge sobreviviente es el heredero tendrá que pagar la legítima a sus exsuegros, con un más que probable enfrentamiento, tanto más si el único bien hereditario es la vivienda conyugal" 24 .

21 María del Mar Manzano-Fernández, Preguntas y respuestas sobre el artículo 857 del Código Civil. La legítima del descendiente del desheredado, 10 Actualidad Civil, 44-55 (2015). Disponible en: http://icat.cataleg-biblioteca.cat/opac/index.php?lvl=author_see\&id=3334

22 A pesar de que no hay un concepto legal de preterición, pueden encontrarse varias definiciones en la doctrina. Obsérvese por ejemplo, el estudio sobre la preterición elaborado por GEMA ALEJANDRA Botana-Garcia, Preterición, 15 Actualidad Civil, Sección Estudios de Jurisprudencia, 1821-1844 (2004). Disponible en: https://dialnet.unirioja.es/servlet/articulo?codigo $=951343$

23 Artículo 814 CC.

24 Xavier O'Callaghan-Muñoz, A vueltas con la desheredación y a revueltas con la legítima, 5 Actualidad Civil, 4-7, 4 (2015). Disponible en: https://goo.gl/1kyuU6 
La legítima del cónyuge viudo ${ }^{25}$ está regulada en los artículos 834 a 840 del CC, que establecen que este ostentará un derecho real de usufructo sobre una parte de la herencia ${ }^{26}$, que dependerá de diversas circunstancias. Así, pueden darse tres situaciones: 1. El cónyuge que al morir su consorte no se hallare separado o lo estuviere por culpa del difunto, si concurre a la herencia con hijos o descendientes, tendrá derecho al usufructo del tercio destinado a mejora ${ }^{27}$. 2. No existiendo descendientes pero sí ascendientes, el cónyuge sobreviviente tendrá derecho al usufructo de la mitad de la herencia ${ }^{28}$. 3. No existiendo descendientes ni ascendientes el cónyuge sobreviviente tendrá derecho al usufructo de los dos tercios de la herencia ${ }^{29}$.

En los siguientes epígrafes, se expondrán los principales rasgos del sistema de legítimas existentes en los territorios forales, donde no resultan de aplicación los rigurosos límites a la libertad de testar descritos con anterioridad, ya que, en virtud de lo establecido en el artículo 149.1.8 de la Constitución Española ${ }^{30}$, estos territorios, denominados forales, tienen competencia ${ }^{31}$ para regular esta institución, cuestión que debe ser criticada ya que como se expondrá, la regulación de la legítima no está armonizada en España, por lo cual se debe criticar el sistema de Derecho Civil en este punto ${ }^{32}$.

25 Hay numerosos estudios sobre esta figura, pero destacan especialmente los relacionados con los efectos de la misma, en caso de separación de los cónyuges. Obsérvese la obra de MARía ÁngeLES Fernández GonzÁlez-Regueral, Separación conyugal: la legítima del cónyuge viudo, La Ley: Revista jurídica española de doctrina, jurisprudencia y bibliografía, 2084-2091 (1997). Obsérvese también la obra de Juan AlBerto Díez-Ballesteros, La separación y sus consecuencias sobre la legítima del cónyuge viudo. Comentario de la resolución de la Dirección General de los Registros y del Notariado de 25 de junio de 1997, La Ley: Revista jurídica española de doctrina, jurisprudencia y bibliografia, 1757-1766 (1999). Disponible en: https://goo.gl/m2Xq9o

26 Es frecuente en la práctica de la sucesión testamentaria que se deje al otro cónyuge el usufructo universal de todos los bienes, lo que amplía claramente los derechos legitimarios del cónyuge superviviente. Sobre esta cuestión y sus consecuencias, obsérvese la obra de Aurelia María Romero-Coloma, Usufructo universal del cónyuge viudo: su problemática jurídica, XXXIII Diario La Ley, 7840, 1-12 (2012). Disponible en: http://mjavierjm-niharra.blogspot.com.es/2012/05/ usufructo-universal-del-conyuge-viudo.html

27 Artículo 834 CC.

28 Artículo 837 CC.

29 Artículo 838 CC.

30 España, Constitución Española, 311 Boletín Oficial del Estado, BOE, 29 de diciembre de 1978. Disponible en: https://www.boe.es/buscar/act.php?id=BOE-A-1978-31229

31 Un estudio sobre las competencias en materia de derecho civil de estos territorios, en la obra de Ángel AcEdo-Penco, Derecho civil autonómico versus derecho civil estatal: estado de la cuestión tras la sentencia del Tribunal Constitucional 31/2010 de 28 de junio, 38 Anuario de la Facultad de Derecho, 245-259 (2010). Disponible en: https://dialnet.unirioja.es/servlet/articulo?codigo=3434370

32 Una visión crítica de la disciplina del derecho civil en general se encuentra en la obra de RoNALD 
El análisis de los regímenes forales seguirá siempre la misma estructura que, coincidirá con la descripción de la institución realizada en los anteriores apartados del trabajo. Por tanto, se comenzará describiendo su origen, su naturaleza jurídica, los herederos forzosos existentes y la cuota legitimaria que les corresponde. Ahora bien, debe notarse que la complejidad de la institución de la legítima no se agota con los conflictos ocasionados dentro del territorio español, sino que, como se ha puesto de manifiesto en otros trabajos, esta complejidad aumenta si se introduce en el caso cualquier elemento de extranjería ${ }^{33}$.

\section{EL RÉGIMEN FORAL GALLEGO}

En el régimen foral gallego ${ }^{34}$, la legítima encontró su primera regulación con la Ley 4/1995, de 24 de mayo, de derecho civil de Galicia $^{35}$, que establecía en su artículo 146.2 que "son legitimarios los herederos forzosos determinados en el Código Civil y en la cuantía y proporción que, en los distintos supuestos, establece dicho cuerpo legal". De la primigenia regulación de esta institución se extrae la conclusión de que, en relación con el objetivo del presente trabajo, todos los factores expuestos en el régimen general de aplicación están reproducidos en la ley gallega, es decir, existirán los mismos herederos forzosos y tendrán derecho a las mismas cuotas hereditarias.

Ahora bien, el sistema descrito quedó derogado con la promulgación de la Ley 2/2006, de 14 de junio, de derecho civil de Galicia ${ }^{36}$ (en adelante, LDCG), cuyo preámbulo proclama una mayor diversificación respecto al derecho común y una profunda acentuación autonómica. En efecto, los cambios introducidos en la institución

Zuleyman Rico-Sandoval, Para una crítica de la violencia del derecho civil, 120 Vniversitas, 169-200 (2010). Disponible en: http://revistas.javeriana.edu.co/index.php/vnijuri/article/view/14455/11652,

33 EsPeranza CASTEllanos-Ruiz, Reenvio, unidad de la sucesión y armonía internacional de soluciones en el derecho sucesorio, 2 International Law: Revista Colombiana de Derecho Internacional, 211-260 (2003). Disponible en: http://www.redalyc.org/articulo.oa?id=82400206

34 Un estudio sobre los orígenes del derecho privado en Galicia puede verse en la reseña de José Ricardo Pardo-Gato, Recensión: Galicia y su derecho privado, de Ramón P. Rodríguez-Montero, 36 Revista Jurídica de Asturias, 271-279 (2013). Disponible en: http://goo.gl/O35kJY

35 España, Ley 4/1995, de 24 de mayo, de derecho civil de Galicia, 152 Boletín Oficial del Estado, BOE, 27 de junio de 1995. Disponible en: https://www.boe.es/diario_boe/txt.php?id=BOE-A-1995-15453

36 España, Ley 2/2006, de 14 de junio, de derecho civil de Galicia, 191 Boletín Oficial del Estado, BOE, 11 de agosto de 2006. Disponible en: https://www.boe.es/buscar/act.php?id=BOE-A-2006-14563 
objeto de estudio por medio de esta norma legal modifican radicalmente el sistema anterior $\mathrm{y}$, por tanto, este sistema se analizará en las siguientes líneas.

En relación con la naturaleza jurídica de la legítima gallega, se debe partir de lo expuesto en los artículos 240 y 243 LDCG. El primero de ellos ordena que "los legitimarios tienen derecho a recibir del causante, por cualquier título, una atribución patrimonial en la forma y medida establecidas en la presente ley", y el segundo precepto dice "constituye la legítima de los descendientes la cuarta parte del valor del haber hereditario líquido". En virtud de la combinación de ambos preceptos, se llega a la conclusión que la legítima gallega puede ser considerada del tipo pars valoris ${ }^{37}$ (derecho de crédito), ya que en palabras de autores de renombre en la disciplina "el heredero forzoso no tiene derecho a una parte de los bienes, sino a un crédito de valor que se fija en dinero, por ello, el legitimario además de no tener acción real para reclamar su legítima, será considerado a todos los efectos como un acreedor" 38 . En este apartado se encuentra la primera diferencia con el régimen general expuesto anteriormente, ya que, como se expuso, la naturaleza jurídica de la legítima del régimen general del $\mathrm{CC}$, era del tipo pars bonorum ${ }^{39}$ (porción de bienes).

Una vez expuesta la naturaleza jurídica de la legítima gallega, es el momento de hacer referencia al sistema de legitimarios del presente régimen foral objeto de estudio. Anteriormente, se hizo mención al artículo 238 LDGC que establecía en su articulado, dos tipos de legitimarios: 1. Los hijos y descendientes de hijos premuertos, desheredados o indignos y, 2. El cónyuge viudo no legalmente separado o de hecho. En virtud de este artículo, se puede observar

37 La naturaleza jurídica de la legítima gallega es estudiada en profundidad en la obra de José L. EspINOSA DE Soto, Capitulo V, de las legítimas, en Derecho de sucesiones y régimen económico familiar de Galicia. Comentarios a los Títulos IX y X y a la disposición adicional tercera de la Ley 2/2006, de 14 de junio y a la Ley 10/2007, de 28 de junio, volumen II, 1550-1630 (Juan M. Cora-Guerreiro, Francisco M. Ordóñez-Armán \& Víctor J. Peón-Rama, coords., Colegio Notarial de Galicia, Madrid, 2007). Antoni Vaquer-Aloy, La legítima en el Derecho civil de Cataluña, en Tratado de Legítimas, 471-515, 483 (Teodora Felipa Torres-García, coord., Editorial Atelier, Barcelona, 2012).

38 Juan José Rivas-Martinez, Derecho de sucesiones. Común y foral, Tomo II, 1853 (4a ed., Editorial Dykinson, Madrid, 2009).

39 La ley gallega de 1995 anteriormente expuesta sí contemplaba en cambio una legítima pars bonorum, como se desprende de lo expuesto entre otros, de la obra de Marta Carballo-Fidalgo, $L a$ legítima en la ley de derecho civil de Galicia, Actualidad Civil, 1553-1578, 1554 (2001). Disponible en: https://goo.gl/iS20YO 
otra importante diferencia del presente régimen foral respecto al sistema de Derecho común, ya que los ascendientes no se consideran legitimarios. Hay autores críticos con esta exclusión ${ }^{40}$, y otros que consideran que esta exclusión debía haber sido acompañada de otras medidas para no quedar desprotegidos por completo a los ascendientes, de suerte tal que "dicha exclusión no ha conllevado la sustitución de la legítima de los padres o ascendientes por otro tipo de derecho sobre la herencia, ni siquiera en caso de necesidad de estos, como podría ser un derecho de alimentos" ${ }^{\prime 4}$.

La exclusión del ascendiente como legitimario o heredero forzoso, no excluye sus derechos como heredero abintestato, en virtud de la remisión realizada por el artículo 267 LDGC al Código Civil en materia de sucesión intestada. Sobre esta remisión, Inmaculada García-Presa ha escrito sobre su naturaleza y llega a la conclusión de que "nos encontramos ante una remisión que se puede calificar como externa, puesto que hace a un ordenamiento diferente. Además surge la duda de si la remisión es estática o dinámica, es decir, si la remisión se realiza al texto vigente actualmente, o la remisión se entiende efectuada a la normativa vigente en cada momento. Mayoritariamente se está a favor del carácter dinámico de la remisión"42.

Por tanto, en la exposición de los legitimarios también se puede encontrar una importante diferencia. Pero las mismas no se agotan con lo expuesto, sino que se acentúan aún más, debido a las cuotas hereditarias a las que los herederos forzosos tienen derecho. En efecto, los hijos y descendientes respecto a las dos terceras partes del haber hereditario que dispone el derecho común, aquí solo disponen de la cuarta parte del valor del haber hereditario líquido ${ }^{43}$, que será objeto de reparto a partes iguales entre los hijos o descendientes.

40 María Mercedes Bermejo-Pumar, El sistema legitimario en la Ley 2/2006, de 14 de junio, de derecho civil de Galicia (primera parte), 65 Revista Jurídica del Notariado, RJN, 9-128, 34 (2008). Disponible en: https://goo.gl/tWUfe8. Esta autora considera que la supresión de los ascendientes como legitimarios es excesivamente drástica.

41 María Paz García-Rubio, Antonia Nieto-Alonso \& Margarita Herrero-Oviedo, Las legítimas en la Ley 2/2006 de Derecho civil de Galicia, en Tratado de legítimas, 203-290, 216 (Teodora Felipa Torres-GarCía, coord., Editorial Atelier, Barcelona, 2012).

42 Inmaculada Garcia-Presas, Visión comparativa del derecho de sucesiones entre la normativa gallega y la estatal, 3 Actualidad Civil, 276-299 (2013).

43 Artículo 243 LDCG: Constituye la legítima de los descendientes la cuarta parte del valor del haber hereditario líquido que, determinado conforme a las reglas de esta sección, se dividirá entre los hijos o sus linajes. 
Además, en este momento, es menester destacar el contenido del artículo 38 LDCG que establece que "la filiación adoptiva produce los mismos efectos que la filiación por naturaleza", es decir, en virtud de este precepto, la legítima del hijo adoptivo y del hijo no adoptivo es exactamente la misma.

La legítima del cónyuge viudo se regula en los artículos 253 a 257 de la LDCG, y le atribuye una cuota usufructuaria que varía en función de los sujetos con los que concurra al llamamiento. Así, en el caso de que concurriera con descendientes del causante, al cónyuge viudo le corresponde en concepto de legítima el usufructo vitalicio de una cuarta parte del haber hereditario, mientras que, en el caso de que no concurriera con descendientes, el cónyuge viudo tendrá derecho al usufructo vitalicio de la mitad del capital. Además, es necesario destacar que el pago de la legítima al cónyuge viudo se realizará de la forma prevista por el causante en el testamento, y a falta de este, se reconoce en el artículo 257 de la norma foral, un derecho preferente del cónyuge viudo, de suerte tal que, "en tanto no exceda de su cuota usufructuaria, el cónyuge viudo podrá optar por hacerla efectiva sobre la vivienda habitual, el local en donde ejerciera su profesión o la empresa que viniera desarrollando con su trabajo".

Antes de terminar la exposición relativa a los derechos legitimarios del cónyuge viudo, se debe poner de manifiesto el contenido de la Disposición Adicional Tercera de la Ley 2/2006, de derecho civil de Galicia, que establece que "a los efectos de la aplicación de la presente ley, se equiparan al matrimonio las relaciones maritales mantenidas con intención o vocación de permanencia, con lo que se extienden a los miembros de la pareja los derechos y las obligaciones que la presente ley reconoce a los cónyuges". Es decir, en virtud de esta disposición se equipara a las parejas de hecho ${ }^{44}$

44 El punto segundo de la Disposición Adicional Tercera establece qué se considera una pareja de hecho y sus exclusiones: "Tendrán la condición de parejas de hecho las uniones de dos personas mayores de edad, capaces, que convivan con la intención o vocación de permanencia en una relación de afectividad análoga a la conyugal y que la inscriban en el Registro de Parejas de Hecho de Galicia, expresando su voluntad de equiparar sus efectos a los del matrimonio. No pueden constituir parejas de hecho: a. Los familiares en línea recta por consanguinidad o adopción. b. Los colaterales por consanguinidad o adopción hasta el tercer grado. c. Los que estén ligados por matrimonio o formen pareja de hecho debidamente formalizada con otra persona". 
con los matrimonios, y la pareja superviviente tendrá los mismos derechos legitimarios que el cónyuge viudo ${ }^{45}$.

\section{EL RÉGIMEN FORAL NAVARRO}

Es el momento de analizar la regulación de la legítima en el régimen foral navarro ${ }^{46}$. Y como se deducirá de lo que se va a exponer, este es un régimen curioso. En primer lugar, se debe hacer mención a la norma que regula la legítima, encontrándose dicha institución en la Ley 1/1973 de 1 de marzo, por la que se aprueba la Compilación del Derecho Civil Foral de Navarra ${ }^{47}$ (fuero nuevo).

Siguiendo con el ítem establecido, sería el momento de abordar la naturaleza jurídica de la legítima de Navarra, pero en este punto se debe hacer mención a lo establecido por la escasa doctrina que ha tratado esta regulación: algunos autores niegan el carácter de legítima. Así, "no existe, propiamente hablando, legítima en Navarra, pues se considera únicamente en sentido formal y, por tanto, basta con no preterir a los hijos, pero haciéndoles exclusivamente atributarios de una disposición de carácter simbólico"48.

La no consideración de una verdadera legítima en el régimen foral objeto de estudio, se debe a lo establecido en la Ley 267 del Fuero Nuevo que establece: "la legítima navarra consiste en la atribución formal a cada uno de los herederos forzosos de cinco sueldos febles o carlines por bienes muebles y una robada de tierra en los montes comunes por inmuebles. Esta legítima no tiene contenido patrimonial exigible ni atribuye la cualidad de heredero, y

45 En la doctrina hay una posición enfrentada sobre el alcance de la figura. Así, hay una visión negativa de ella en la obra de José MANUEl Busto-LAGo, Elementos para una interpretación no perturbadora de la equiparación al matrimonio de las relaciones more uxorio realizada por la Disposición Adicional Tercera de la LDCG 2006, 726 Actualidad Jurídica Aranzadi, 1-19, 4 ss. (2007). Disponible en: https://goo.gl/V2AEjj. En cambio, hay una opinión favorable en la obra de MARÍA PAz GARCíARuBIo, Las parejas de hecho en el derecho civil gallego o cómo la corrección política da palos de ciego, 16 Revista Xurídica da Universidade de Santiago de Compostela, 1, 187-208, 198 ss. (2007). Disponible en: http://dspace.usc.es/handle/10347/7872

46 Un estudio sobre el alcance de las competencias en materia de Derecho Civil por parte de la comunidad autónoma de Navarra, puede encontrarse en la obra de LUIS IGNACIO ARECHEDERRA-ARANZADI, Competencia en materia de derecho civil, Diario La Ley, 950-1110, 1074 (1986).

47 España, Ley 1/1973, de 1 de marzo, por la que se aprueba la Compilación del Derecho Civil Foral de Navarra, 57 Boletín Oficial del Estado, BOE, 7 de marzo de 1973. Disponible en: https://www.boe.es/ buscar/doc.php?id=BOE-A-1973-330, https://www.boe.es/diario_boe/txt.php?id=BOE-A-1987-13331

48 Carlos Lasarte-Álvarez, Principios de derecho civil VII, Derecho de sucesiones, 171 (10 ed., Editorial Marcial Pons, Madrid, 2015). 
el instituido en ella no responderá en ningún caso de las deudas hereditarias ni podrá ejercitar las acciones propias del heredero". Además, en palabras de otros autores destacados, no solo no existe una verdadera legítima, sino que, cuando solo se deja al heredero el contenido de la legítima descrito en el precepto anterior, se está produciendo en la práctica una verdadera desheredación, de suerte tal que "esta norma es también conocida como legítima foral formularia o fórmula de desheredación; y ello es así, pues si al legitimario solo se le instituye en la legítima formal, se produce respecto de él una efectiva y evidente desheredación" $"$.

En relación con quiénes son los sujetos considerados legitimarios en el presente régimen foral, se debe destacar que solo ostentan esta condición los hijos, propios y adoptivos, y a falta de estos, los descendientes más próximos ${ }^{50}$. Por tanto, se puede observar que, ni los ascendientes, ni el cónyuge viudo son considerados legitimarios en este régimen.

La cuota atribuida a los legitimarios, como se avanzó anteriormente, es relativamente escasa o nula. En efecto, del contenido del Artículo 267 del Fuero Nuevo, se puede obtener que la legítima de los herederos forzosos será de cinco sueldos febles o carlines $^{51}$ por bienes muebles y una robada (antiguo sistema de medición agrario) de tierra en los montes comunes por inmuebles. Por tanto, y teniendo en cuenta la ausencia de contenido patrimonial de la cuota legitimaria, se puede compartir el argumento consistente en que más que instituir como heredero al legatario, incluirlo en

49 Juan José Rivas-Martínez, Derecho de sucesiones. Común y foral, Tomo II, 1827 (4a ed., Editorial Dykinson, Madrid, 2009).

50 Artículo 268 del Fuero Nuevo: El testamento y pactos sucesorios deberán ser instituidos en la legítima foral: 1. Los hijos matrimoniales, los no matrimoniales y los adoptados con adopción plena. 2. En defecto de cualquiera de ellos, sus respectivos descendientes de grado más próximo.

51 El sueldo era una moneda antigua que equivalía a medio real. El sueldo carlín era una moneda navarra de plata y vellón de la Edad Media. Había carlines blancos y negros; los blancos tenían mayor valor, mientras que los negros poseían un menor valor debido a su contenido de plata de menor ley. Con el paso del tiempo, las acuñaciones fueron a peor y los carlines negros, con una calidad o ley de plata cada vez menor, se subdividieron a su vez en fuertes y febles o débiles, siendo estos últimos de un valor ínfimo. Pero el significado de esta herencia hay que mirarlo con lupa, pues el sueldo carlín no es de curso legal y, por tanto, su valor es igual a cero. Asimismo, la robada de tierra en los montes comunales carece de la más mínima eficacia, ya que los ayuntamientos, como titulares que son, pueden disponer del uso y disfrute de las tierras del común. En definitiva, el valor económico de estos sueldos es casi inferior a la nada más absoluta y dejar en herencia una robada en los montes comunales es como regalar el aire que se respira, en un alarde y un derroche inaudito de generosidad. 
el testamento solamente con la legítima foral navarra supone una verdadera desheredación fáctica.

\section{EL RÉGIMEN FORAL CATALÁN}

El origen de la institución de la legítima en este régimen foral es fruto de una larga evolución. En síntesis, se debe indicar que entre la Constitución de Alfonso III en 1333, hasta la Constitución de 1585 de las Cortes de Monzón, regía el sistema romano ideado por Justiniano, ya explicado anteriormente en el presente trabajo, donde se atribuía como legítima la mitad del caudal hereditario si existían más de cuatro hijos, y un tercio si eran menos. Desde la constitución de Felipe II de 1585 en las Cortes de Monzón, hasta la compilación de Derecho civil realizada en 1960, se estableció un sistema que, como se explicará, todavía dura en la actualidad e impone una legítima de un cuarto del haber hereditario. Desde 1960 hasta la regulación actual, que será objeto de análisis, la Ley de 9 de abril de 1990 del parlamento de Cataluña reguló esta cuestión ${ }^{52}$.

Actualmente, la legítima catalana tiene su encaje normativo en la Ley 10/2008, de 10 de julio, del libro cuarto del Código Civil de Cataluña (en adelante, CCCat), relativo a las sucesiones ${ }^{53}$. En relación con la naturaleza jurídica de la institución, se debe indicar que está regulada como una pars valoris (derecho de crédito), lo que vuelve a demostrar en este punto, una sustancial diferencia con la regulación de esta institución en el régimen común. Esta consideración se extrae de lo establecido en el artículo 451.1 CCCat, "la legítima es el derecho a obtener en la sucesión del causante un valor patrimonial que este puede atribuir a título de institución hereditaria, legado, atribución particular o donación de cualquier otra forma".

La naturaleza jurídica de la legítima catalana no se agota con lo establecido anteriormente, sino que es necesario poner de manifiesto la opinión de diversos autores. En efecto, la regulación actual, aunque actúa como un límite a la libertad de testar, como se expondrá, realmente está muy debilitada, ya que solo se fija una

52 RAmÓn MARÍA Roca-SAStre, Estudios sobre sucesiones, 512 (Editorial Instituto de España, Madrid, 1981).

53 España, Ley 10/2008, de 10 de julio, del libro cuarto del Código Civil de Cataluña, relativo a las sucesiones, 190 Boletín Oficial del Estado, BOE, 7 de agosto de 2008. Disponible en: https://www. boe.es/diario_boe/txt.php?id=BOE-A-2008-13533 
cuota hereditaria de un cuarto del caudal hereditario, que podrá ser pagada incluso con bienes extrahereditarios. De suerte tal que "el causante es libre de disponer de sus bienes como mejor le plazca, sin tener ninguna obligación de reservar bien alguno para alguno de sus legitimarios. En este sentido, la legítima no corta la libertad de disponer del causante, sino que garantiza al legitimario una participación mínima en el valor de la herencia con independencia del destino que haya deseado otorgar a esta el testador" ${ }^{54}$.

Una vez expuesto el origen y la naturaleza jurídica de la institución, es menester, siguiendo el orden establecido, hacer referencia a los legitimarios del régimen. El artículo 451.3 CCCat establece que son legitimarios los hijos del causante y, en el caso de que estos no puedan suceder, sus descendientes ${ }^{55}$. Además, los otros sujetos con derecho a legítima serán los ascendientes, aunque solo ostentarán esta condición, en el caso de que no existan descendientes, en virtud de lo establecido en el artículo 451.4 CCCat, "si el causante no tiene descendientes que le hayan sobrevivido, son legitimarios los progenitores por mitad. Estos no tienen derecho a legítima si el causante tiene descendientes pero han sido desheredados justamente o declarados indignos".

Como se puede observar, el cónyuge viudo no ostenta ningún derecho legitimario, se encuentra aquí, otra importante diferencia del régimen establecido en el derecho común. Pero esta afirmación no es del todo cierta. En efecto, aunque la regulación actual, no incluye entre los sujetos legitimarios al cónyuge viudo, no es menos cierto que tampoco se olvida completamente de esta figura. Así, el artículo 452 CCCat regula la denominada cuarta viudal, de suerte tal que el cónyuge viudo o el conviviente en unión estable de pareja

54 Antoni Vaquer-Aloy, La legítima en el Derecho civil de Cataluña, en Tratado de Legítimas, 471515, 483 (Teodora Felipa Torres-García, coord., Editorial Atelier, Barcelona, 2012).

55 Artículo 451.3 CCCat: 1. Son legitimarios todos los hijos del causante por partes iguales.2. Los hijos premuertos, los desheredados justamente, los declarados indignos y los ausentes son representados por sus respectivos descendientes por estirpes. 3. El derecho de representación solo tiene por objeto el derecho a la legítima y no se extiende a las atribuciones patrimoniales que el causante haya ordenado a favor del representado, salvo que el representante haya sido llamado por vía de sustitución. 4. En caso de adopción de hijos del cónyuge o de la persona con quien el adoptante convive en relación de pareja con carácter estable, el adoptado no es legitimario del progenitor de origen sustituido por la adopción y, si este ha muerto, tampoco lo es, por derecho de representación, en la sucesión de los ascendientes de este. La misma regla se aplica en la adopción de huérfanos por parientes dentro del cuarto grado respecto a la sucesión de los ascendientes de la rama familiar en que no se ha producido la adopción. 
que, con los bienes propios, los que puedan corresponderle por razón de liquidación del régimen económico matrimonial y los que el causante le atribuya por causa de muerte o en consideración a esta, no tenga recursos económicos suficientes para satisfacer sus necesidades tiene derecho ${ }^{56}$ a obtener en la sucesión del cónyuge o conviviente premuerto la cantidad que sea precisa para atenderlas, hasta un máximo de la cuarta parte del activo hereditario líquido.

Es el momento de hacer referencia a la cuota legitimaria, que como ya se avanzó anteriormente, asciende a un cuarto del haber hereditario, como establece el artículo 451.5 CCCat. Además, se trata de una legítima inamovible, que será recibida por los hijos o descendientes, independientemente del número que formen, es decir, si existen cuatro hijos, estos deberán repartirse a partes iguales este derecho de crédito de la cuarta parte del haber hereditario. Como se estableció, en caso de que no existan descendientes, serán los progenitores los que se repartan en partes iguales esta cuarta parte, y se utiliza el término progenitores y no el de ascendientes, debido a que en esta figura no opera el derecho de representación del resto de ascendientes.

En último lugar, y a pesar de que en el presente trabajo no se han realizado menciones especializadas en relación con las causas de desheredación de los legitimarios, se debe destacar una establecida en este régimen foral que ha provocado un gran revuelo en la doctrina. En efecto, el artículo $451.17 \mathrm{CC}$ establece como causa de desheredación la ausencia manifiesta y continuada de relación familiar entre el causante y el legitimario, si es por una causa exclusivamente imputable al legitimario. En el sistema de Derecho común, no hay ninguna causa relativa a la falta de relación de los hijos con sus progenitores; esta situación provoca que los tribunales no se puedan referir a la misma de manera expresa para admitir o denegar causas de desheredación. Así, destaca la Sentencia del Tribunal Supremo (en adelante, TS) de 3 de junio de 2014, en su

56 Se debe indicar que este derecho no tiene un carácter absoluto, sino que el artículo 452.6 CCCat regula unas causas de exclusión. El derecho a reclamar la cuarta viudal se extingue: a. Por renuncia hecha después de la muerte del causante. b. Por matrimonio o convivencia marital con otra persona, después de la muerte del causante y antes de haberlo ejercido. c. Por la muerte del cónyuge viudo o el conviviente en unión estable de pareja superviviente sin haberlo ejercido. d. Por suspensión o privación de la potestad del cónyuge viudo o conviviente en unión estable de pareja superviviente, por causa que le sea imputable, sobre los hijos comunes con el causante. 2. La pretensión para reclamar la cuarta viudal prescribe al cabo de tres años de la muerte del causante. 
Sala de lo Civil ${ }^{57}$, en la que equipara la situación de abandono de un progenitor, debido a que sus hijos no querían mantener relación con su persona, a una situación de malos tratos psicológicos. En el fondo, el debate existente, en relación con esta causa, deriva en su inclusión en el derecho común o no ${ }^{58}$, ya que, en muchos casos en que se produce un abandono de los hijos a alguno de sus progenitores, muchas veces motivados por causas de divorcio entre ellos, y el progenitor agraviado quiere desheredar a sus hijos por ese abandono, los Tribunales no conceden esta finalidad, debido a la falta de tipificación de la conducta ${ }^{59}$.

\section{EL RÉGIMEN FORAL ARAGONÉS}

Explicar la regulación de la institución de la legítima en este régimen de una manera sintética es tarea complicada, pues no fácil hacerlo en pocas líneas. Y esto es así, en gran parte, por los antecedentes históricos del derecho foral aragonés, los cuales serán descritos de manera breve ${ }^{60}$, para continuar de este modo, con la estructura utilizada en los anteriores epígrafes del presente trabajo.

57 Un estudio completo de los efectos y consecuencia de este pronunciamiento puede encontrarse en la obra de Esther Arroyo i Amayuelas \& Esther Farnós-Amorós, Entre el testador abandonado y el legitimario desheredado ¿a quién prefieren los tribunales?, 2 InDret, 1-32 (2015). Disponible en: http://www.indret.com/pdf/1132_es.pdf

58 Véase la postura favorable de Antoni VAQUER-Aloy, Freedom of Testation, Compulsory Share and Disinheritance Based on Lack of Family Relationship, en The Law of Succession: Testamentary Freedom. European Perspectives, 89-104, 101-103 (Miriam Anderson \& Esther Arroyo i Amayuelas, eds., Editorial Europa Law Publishing, Groningen, 2007). En cambio, obsérvese la postura contraria de Jordi Ribot-Igualada, Comentario al art. 451-17 CC Cat, en Comentari al llibre quart del Codi civil de Catalunya, relatiu a les successions, II, X-X, 1393-1418, 1402 (JoAn EgEA-I-FernÀndez \& J. Ferrer-Riba, dirs., Editorial Atelier, Barcelona, 2009).

59 Véase por ejemplo, la Sentencia de la Audiencia Provincial de Castellón, del 27 de octubre de 2004, concretamente su fundamento jurídico segundo, que establece: "los padres se separaron antes de su nacimiento, sin cumplir el padre con sus obligaciones alimentarias y de educación del mismo. Solo existió un intento de acercamiento por parte del padre cuando el hijo ya era mayor de edad, siéndole entonces negado por el hijo. Y este comportamiento no es causa suficiente de desheredación conforme a lo establecido en el Código Civil". En el mismo sentido se pronuncia la sentencia de la Audiencia Provincial de Palencia de 4 de noviembre de 2005, también en su fundamento jurídico segundo al establecer: "la separación motivó el alejamiento y las malas relaciones entre los padres y los hijos. Ahora bien, en momento alguno se ha acreditado la existencia de malos tratos de obra o injurias graves. No hay base, pues, alguna para entender acreditada la causa de desheredación".

60 Un estudio completo de la historia de la legítima en Aragón, donde se destacan las influencias del sistema de common law, se encuentra en la obra de Aurelio Barrio-Gallardo, Estudio históricocomparado de la libertad de testar en Inglaterra y Aragón, XVII Revista de Derecho Civil Aragonés, RDCA, 45-92 (2011). Disponible en: http://ifc.dpz.es/recursos/publicaciones/32/29/02barrio.pdf 
El rasgo más remoto de la institución aparece en 1142 con el Fuero de Daroca, concedido por el conde de Barcelona y príncipe de Aragón Ramón Berenguer IV, que establecía una distribución igualitaria entre los hijos del caudado hereditario. Posteriormente, en 1187, el Fuero de Jaca, de Alfonso II, estableció una absoluta libertad de testar, libertad que desapareció con los Fueros de Daroca, De testamentis civium, en 1311, de Jaime II, donde se obligaba a incluir en el testamento al menos a uno de los herederos. Ya en el siglo XX, el Código civil de Aragón de 1925 estableció una legítima de un tercio del caudal hereditario en el caso de que existiera un descendiente y, de dos tercios en el caso de que hubiera dos o más.

En la actualidad, el Código Civil aragonés ha sufrido reformas por varias leyes ${ }^{61}$ y está vigente el Decreto Legislativo 1/2011, de 22 de marzo, del Gobierno de Aragón, por el que se aprueba, con el título de Código del Derecho Foral de Aragón, el Texto Refundido de las Leyes civiles aragonesas ${ }^{62}$, (en acrónimo CDFA). La legítima en cuanto a su naturaleza jurídica se encuentra constituida como una porción de bienes que se atribuyen a los legitimarios, por tanto, tiene un carácter de pars bonorum, en virtud de lo establecido en el artículo 497.1 CDFA al establecer "la legítima debe atribuirse en bienes relictos". Respecto a la naturaleza jurídica de esta institución, existió un enorme debate en la doctrina, fundamentalmente con anterioridad a la modificación ${ }^{63}$ efectuada por la Ley de Sucesiones de 1999, aunque con la redacción actual, prácticamente existe una idea unánime en la doctrina en su consideración como una porción de bienes ${ }^{64}$.

61 La última gran reforma ha sido efectuada por la Ley 1/1999, de 24 de febrero, de sucesiones por causa de muerte, Boletín Oficial del Estado, «BOE» núm. 72 de 25 de Marzo de 1999. Disponible en: https://www.boe.es/boe/dias/1999/03/25/pdfs/A11723-11750.pdf

62 España, Decreto Legislativo 1/2011, de 22 de marzo, del Gobierno de Aragón, por el que se aprueba, con el título de Código del Derecho Foral de Aragón, el Texto Refundido de las Leyes civiles aragonesas, Boletín Oficial del Estado, «BOE», núm. 67, de 29 de marzo de 2011. Disponible en: http://www.boa.aragon.es/cgi-bin/eboa/brscgi?cmd=verobj\&mlkob=588310770505

63 Obsérvese, por ejemplo, la obra de José Luis LaCRuZ-Berdejo, Las legitimas en la compilación, XLIV Revista Crítica de Derecho Inmobiliario, 505-540, 515 (1968). Disponible en: http://goo.gl/ VI9ITk, en la que defendía la naturaleza de pars valoris de la legítima aragonesa. Disponible en: http://goo.gl/VI9ITk

64 Obsérvese por ejemplo, la obra de José Antonio SERrano-García, La legítima en Aragón, en Tratado de derecho de sucesiones: código civil y normativa civil autonómica: Aragón, Baleares, Cataluña, Galicia, Navarra, País Vasco, 1850-1945 (María del Carmen Gete-Alonso y Calera, Editorial Thomson Reuters, Navarra, 2011). 
Es el momento de hacer referencia a los legitimarios. En el Derecho Foral Aragonés, el artículo 486 CDFA establece que, "la mitad del caudal debe recaer en descendientes, de cualquier grado, del causante, que son los únicos legitimarios. Esta legítima colectiva puede distribuirse, igual o desigualmente, entre todos o varios de tales descendientes, o bien atribuirse a uno solo. Si no se ha distribuido o atribuido de otra manera, la legítima colectiva se entiende distribuida entre los legitimarios de grado preferente conforme a las reglas de la sucesión legal". Del precepto expuesto, tres cuestiones se pueden obtener: 1) La cuota hereditaria ya queda claramente fijada, asciendo la misma a la mitad del caudal hereditario, 2) Solo existe un grupo de legitimarios, los descendientes y, 3) Se trata de una legítima colectiva y no individual.

Los puntos segundos y terceros descritos con anterioridad, merecen ser objeto de desarrollo. Así, en primer lugar, se debe hacer referencia a los descendientes como legitimarios. Los descendientes, como después se expondrá, tienen derecho de forma colectiva a un cuarto del caudal hereditario, pero además, estos se dividen en dos grupos, ya que, existirán legitimarios de grado preferente ${ }^{65}$ y, legitimarios que no ostenten dicha cualidad. En realidad, esta distinción no afecta al causante, sino que solamente produce efectos entre los legitimarios, ya que solo los que ostenten la condición de privilegio podrán considerarse preteridos en el testamento y reclamar los derechos que les corresponden ${ }^{66}$.

La segunda cuestión que se anunció que sería objeto de análisis, es la correspondiente al carácter colectivo de la legítima. Este carácter se extrae del contenido del artículo 486 CDFA descrito anteriormente, y supone que la cuarta parte del caudal hereditario puede ser dejada expresamente para cualquiera de los descendientes, de suerte tal que, "es el grupo de descendientes, en su conjunto, el que ha recibido o debe recibir el importe de la legítima, sin que ninguno de ellos tenga derecho a recibir una porción concreta. (...) El mismo carácter colectivo lleva implícita la facultad de desigua-

65 Según el artículo 488 CDFA son legitimarios preferentes: 1. Son legitimarios de grado preferente los hijos y, en lugar de los premuertos, desheredados con causa legal o indignos de suceder, sus respectivos hijos, sustituidos en los mismos casos y sucesivamente por sus estirpes de descendientes. No tendrán esta condición los descendientes de los que hubieran renunciado a su legítima.

66 Joaquín Cereceda-Marquínez, Ley de sucesiones, Título VI, De la legítima, 5 Revista de Derecho Civil Aragonés, RDCA, 1, 111-122 (1999). 
lar a los hijos, u otros descendientes" ${ }^{97}$. Ahora bien, en el caso de que no se distribuya la cuota, esta se entiende repartida en partes iguales entre los legitimarios de derecho preferente.

En la presente regulación, no ostentan la condición de legitimario ni los ascendientes ni el cónyuge viudo. Pero esta segunda figura tiene un matiz, ya que, al igual que se expuso en el caso de Cataluña, hay un sistema alternativo de protección de la misma. En efecto, los artículos 271 a 302 CDFA regulan un derecho de viudedad, que será expectante, mientras no se produzca el fallecimiento del otro cónyuge, y se convertirá en vitalicio y universal tras el fallecimiento del mismo, que existirá, aunque se pacte separación de bienes entre los cónyuges. Aunque, como nota negativa, se debe indicar que la pareja que no esté casada, en virtud del régimen establecido en los artículos 303 a 315 CDFA no ostentará este derecho ${ }^{68}$.

En último lugar dentro de este régimen, cabe resaltar la posibilidad existente de no nombrar heredero a ningún legitimario, pudiendo ser nombrado heredero un extraño, incluso en concurrencia con legitimarios, siempre que dicho nombramiento se realice de forma clara y explícita. Así, lo establece el artículo 487.2 CDFA, "la existencia de legitimarios no impide al disponente instituir, de forma clara y explícita, heredero a un extraño". La razón de ser de este precepto estriba, en que los legitimarios han podido recibir su legítima en vida, mediante una donación por ejemplo, de suerte tal que "no es obligatorio designar heredero a alguno de los legitimarios: estos han podido recibir en vida del causante el importe de la legítima mediante donaciones o pueden recibirlo a su muerte mediante legados si el disponente ha instituido heredero, de forma clara y explícita, a un extraño" ${ }^{\circ 9}$.

67 María Ángeles Parra-Lucán \& Aurelio Barrio-Gallardo, La legítima en derecho aragonés, en Tratado de legítimas, 359-416, 362 (Teodora Felipa Torres-García, coord., Editorial Atelier, Barcelona, 2012).

68 Sobre este asunto, puede consultarse la obra de María Martínez-Martínez, Sucesión legal y usufructo viudal de cónyuge separado de hecho (Comentario a la Sentencia del Tribunal Superior de Justicia de Aragón de 25 de junio de 2007), 2 Revista de Derecho Civil Aragonés, RDCA, 193-218 (2008). Disponible en: http://derecho-aragones.net/cuadernos/document.php?id=459. Véase también la obra de María Ángeles Parra-Lucán, La viudedad, en Tratado de derecho de sucesiones: código civil y normativa civil autonómica: Aragón, Baleares, Cataluña, Galicia, Navarra, País Vasco, 2100-2270 (María del Carmen Gete-Alonso y Calera, Editorial Thomson Reuters, Navarra, 2011).

69 José Antonio Serrano-García, La legítima en Aragón, XVI Revista de Derecho Civil Aragonés, $R D C A, 67-134,83$ (2010). Disponible en: http://ifc.dpz.es/recursos/publicaciones/30/96/02serrano. pdf, http://goo.gl/Rf44ok 


\section{EL RÉGIMEN FORAL BALEAR}

El Decreto Legislativo 79/1990, de 6 de septiembre, por el que se aprueba el texto refundido de la compilación del Derecho Civil de las Islas Baleare ${ }^{70}$ (en adelante, CDCIB) regula el sistema legitimario en las Islas Baleares. El origen de esta institución no alberga la misma antigüedad, que el resto de los derechos forales explicados con anterioridad, ya que la primera regulación data de la Ley 5/1961, de 19 de abril, por la que se aprueba la Compilación del Derecho civil especial de las Islas Baleares ${ }^{71}$. La legítima tiene rasgos distintos en las diferentes islas que componen Baleares y se expondrá en primer lugar el régimen previsto en Mallorca y Menorca.

Antes de hacer referencia a los puntos desarrollados en los anteriores epígrafes, se debe hacer mención a una notable diferencia de la regulación de la institución en este territorio foral, ya que la legítima no está regulada como una limitación de la libertad de testar del testador, sino como su vertiente primera positiva; así lo establece el artículo 48 CDCIB, "la legítima atribuye derecho a una porción del haber hereditario". Así, "la legítima confiere a los legitimarios en la sucesión de su causante un derecho sobre una parte del haber hereditario en la cuantía designada, y, a diferencia de otros sistemas jurídicos, en el ordenamiento balear la legítima no se concibe como una limitación al poder de disposición del causante, sino como un derecho del legitimario"72.

\section{A. La regulación en las Islas de Mallorca y Menorca}

En relación con la naturaleza jurídica de la institución, la legítima en Mallorca y Menorca podrá ser atribuida por cualquier título y se configura como pars bonorum, ya que como establece el artículo 48 CDCIB: "la legítima atribuye derecho a una porción del haber

70 España, Decreto Legislativo 79/1990, de 6 de septiembre, por el que se aprueba el texto refundido de la compilación del derecho civil de las Islas Baleares, 120 Boletín Oficial del Estado, BOE, 2 de octubre de 1990. Disponible en: https://www.boe.es/buscar/doc.php?id=BOIB-i-1990-90001

71 España, Ley 5/1961, de 19 de abril, por la que se aprueba la compilación del derecho civil especial de las Islas Baleares, 95 Boletín Oficial del Estado, BOE, 21 de abril de 1961. Disponible en: https:// www.boe.es/diario_boe/txt.php?id=BOE-A-1961-7734

72 María del Carmen Vila-Ribas, María Pilar Ferrer-Vanrell \& Pedro A. Munar-Bernat, La legítima en el derecho civil de las Islas Baleares, en Tratado de legítimas, 291-358, 312 (TEOdORA Felipa Torres-García, coord., Editorial Atelier, Barcelona, 2012). 
hereditario, y debe ser pagada en bienes de la herencia”. En este caso, se formaría una comunidad de bienes, en la cual el legitimario es considerado copropietario de los bienes hereditarios, condición que ostentará hasta el momento de la práctica de la partición.

El artículo 41 CDCB establece que serán legitimarios los hijos y descendientes, los padres, en ausencia de los anteriores y el cónyuge viudo $^{73}$. En relación con la cuantía de la legítima, en el caso de los descendientes depende del número de hijos, si son menos de cuatro o cuatro, estos tienen derecho a un tercio del haber hereditario, mientras que si son más de cuatro la legítima se reduce a la mitad del caudal hereditario, como establece el artículo 42 del citado cuerpo legal. En caso de ausencia de descendientes legitimarios, la cuantía de la legítima de los padres ascenderá a una cuarta parte del haber hereditario.

Y por último, se debe destacar el contenido del artículo 45 CDCIB que establece que al cónyuge viudo le corresponde el usufructo de la mitad del caudal hereditario cuando concurra este con descendientes. Si concurre con los padres del causante tendrá derecho al usufructo de dos tercios. Y, en último lugar, tendrá derecho al usufructo universal cuando no concurra ni con hijos ni con padres del causante.

\section{B. La regulación en las islas de Ibiza y Formentera}

En las Islas de Ibiza y Formentera, según el artículo 79 CDCIB, serán legitimarios los hijos y descendientes, y los padres, tanto naturales como adoptivos. En relación con la cuantía de la legítima que les corresponde a los hijos y descendientes, al igual que en las otras islas, la misma varía en función del número de hijos; si son menos de cuatro o cuatro, estos tienen derecho a un tercio del haber hereditario, mientras que si son más de cuatro la legítima aumenta a la mitad del caudal hereditario.

La cuantía legitimaria de los padres se rige por lo establecido en los artículos 809 y 810 del Código Civil, ya que el precepto analizado anteriormente se remite al texto del territorio común de forma

73 Artículo 41 CDCIB: Son legitimarios, en los términos que resultan de los artículos siguientes: 1. Los hijos y descendientes por naturaleza, matrimoniales y no matrimoniales, y los adoptivos. 2 . Los padres, por naturaleza o adopción. 3. El cónyuge viudo. 
supletoria. La cuota se corresponderá por tanto, con la mitad del caudal hereditario si el hijo fallece sin estar casado, y en el caso de que concurra con el cónyuge viudo, la legítima desciende a una tercera parte.

En relación con el cónyuge viudo ${ }^{74}$ o pareja de hecho, a pesar de que no se le concede la categoría de legitimario, conservará sus derechos en la sucesión ab intestato, en virtud de lo establecido en el artículo 84 CDCIB que establece que el cónyuge tendrá derecho a recibir en usufructo la mitad del caudal hereditario cuando este concurra con descendientes y si concurre con ascendientes el usufructo será de dos tercios.

\section{EL RÉGIMEN FORAL DEL PAís VASCO}

En el presente trabajo, se ha dejado para analizar en último lugar la institución de la legítima recogida en el País Vasco, debido a lo complejo de su regulación, aunque para no faltar con la verdad, como se expondrá, la regulación actual ha reducido la complejidad que existía anteriormente.

La primera regulación contemporánea aparece con la Ley 3/1992, de 1 de julio, del Derecho Civil Foral del País Vasco ${ }^{75}$, actualmente derogada. En ella, se encontraba una regulación de la institución muy compleja, ya que había cuatro regulaciones distintas que se aplicarían en función del territorio, de suerte tal que en Guipúzcoa existía el Fuero guipuzcoano que resultaba de aplicación para los sujetos con vecindad civil en esa localidad y, fueran propietarios de un caserío en ese territorio. Existía además, el Derecho especial alavés que concentraba su vigencia en la Tierra de Ayala, y el Fuero de Bizkaia que no regía en todo ese territorio, sino en la parte conocida como Infanzonado. En el resto del territorio vasco, era de aplicación la regulación de la legítima contenida en el Código Civil de derecho común. De estos tres regímenes especiales expuestos ${ }^{76}$,

74 Véase Pedro Grimalt-Servera, Los derechos legitimarios y legitimos del cónyuge viudo separado en el Código Civil español y en la compilación del derecho civil de las Islas Baleares, 3 Actualidad Jurídica Iberoamericana, 565-576 (2015). Disponible en: http://roderic.uv.es/handle/10550/47085

75 España, Ley 3/1992, de 1 de julio, del Derecho Civil Foral del País Vasco, 39 Boletín Oficial del Estado, BOE, 15 de febrero de 2012. Disponible en: https://www.boe.es/diario_boe/txt.php?id=BOEA-2012-2257

76 En palabras de un autor destacado vasco, "Alava, Guipúzcoa y Bizkaia son provincias hermanas, pero en modo alguno idénticas, cada una tiene su historia y sus usos y costumbres, que podrán ser 
solo los últimos dos contaban con un verdadero sistema de legítima propio, ya que el Fuero guipuzcoano se limitaba a modular la aplicación del régimen general previsto en $\mathrm{CC}$ español ${ }^{77}$.

Una vez realizada una pequeña referencia histórica, que será ampliada posteriormente en el estudio pormenorizado del régimen actual, es menester hacer la primera referencia a la regulación vigente en este momento. Así, la Ley 5/2015, de 25 de junio, de Derecho Civil Vasco $^{78}$ (en adelante, LDCV), modifica la norma anterior de 1992 y produce una simplificación manifiesta de la regulación de la institución, ya que, como se expondrá, introduce un régimen general de aplicación para el territorio vasco, con excepción de dos singularidades: la de los Fueros vizcaínos, donde destaca el elemento de la troncalidad y, la del Derecho Alavés (Tierra de Ayala), donde impera la libertad absoluta de testar.

\section{A. Análisis del régimen general vasco}

Siguiendo con lo establecido, en primer lugar, se debe hacer referencia al régimen general, para finalizar con el sistema legitimario de las dos especialidades que hay en la actualidad. De este modo, será de aplicación al territorio vasco (excepto en la Tierra de Ayala y los Fueros vizcaínos) el siguiente régimen. El artículo 47 LDCV establece que son legitimarios, dos sujetos: por un lado, los hijos o descendientes en cualquier grado y, por otro, el cónyuge viudo o miembro superviviente de la pareja de hecho por su cuota usufructuaria, en concurrencia con cualquier clase de herederos. En vista de lo anterior, los ascendientes no ostentan la cualidad de legitimarios.

Una de las cuestiones discutidas por la doctrina es la relativa a la naturaleza jurídica de esta legítima. En efecto, el artículo 48.1 complica esta calificación debido a su deficiente redacción, estableciendo que "la legítima es una cuota sobre la herencia, que se

semejantes, pero nunca iguales", en Adrí́n CELAYA-IBARra, Nuestra libertad de testar, 8 Jado: Boletín de la Academia Vasca de Derecho = Zuzenbidearen Euskal Akademiaren Aldizkaria, 19, 7-16, 10 (2010). Disponible en: https://dialnet.unirioja.es/servlet/articulo?codigo=3329486

77 Un estudio completo sobre la anterior regulación de la institución en el País Vasco, puede encontrarse en la obra de Gorka Horacio Galicia-Aizpurua, Legítimas y libertad de testar en el País Vasco, en Tratado de legítimas, 417-470 (TeOdora Felipa Torres-García, coord., Editorial Atelier, Barcelona, 2012).

78 España, Ley 5/2015, de 25 de junio, de derecho civil vasco, 176 Boletín Oficial del Estado, BOE, 24 de julio de 2015. Disponible en: https://www.boe.es/diario_boe/txt.php?id=BOE-A-2015-8273 
calcula por su valor económico, y que el causante puede atribuir a sus legitimarios a título de herencia, legado, donación o de otro modo". La introducción de la expresión se calcula por su valor económico puede hacer referencia a la consideración de la legítima como una pars valoris, por lo cual esta regulación se asemeja a la ya estudiada anteriormente en el régimen foral catalán o el gallego ${ }^{79}$.

En relación con la legítima de los descendientes, al igual que en el caso de Aragón, la misma está configurada de manera colectiva, como se advierte de lo establecido en el artículo 48.2 LDCV, "el causante está obligado a transmitir la legítima a sus legitimarios, pero puede elegir entre ellos a uno o varios y apartar a los demás, de forma expresa o tácita”. Además, el causante en su testamento podrá dejar esta legítima a cualquier descendiente, es decir, podrá dejársela a un nieto, aun existiendo su hijo con vida ${ }^{80}$, por tanto, salvo en el caso de que existe un solo descendiente, el cual tendrá derecho a una porción individual, no existirán más atribuciones individuales obligatorias, sino que serán colectivas. En último lugar, se debe mencionar la cuota correspondiente a los descendientes, que asciende a un tercio del caudal hereditario, como establece el artículo 49 LDCV.

El segundo grupo de legitimarios es el representado por el cónyuge o pareja de hecho supérstite. El artículo 52 LDCV establece la extensión de sus derechos legitimarios que revestirán el carácter de derecho real de usufructo y, al igual que ocurre en el resto de regímenes, dependerá de si concurre o no con descendientes a la sucesión. Así, el cónyuge viudo o miembro superviviente de la pareja de hecho tendrá derecho al usufructo de la mitad de todos los bienes del causante si concurriere con descendientes. En defecto de descendientes, tendrá el usufructo de dos tercios de los bienes. Además, se reconoce una singularidad, ya que también tendrá derecho a un derecho real de habitación sobre la vivienda familiar ${ }^{81}$.

79 Una interesante y profunda reflexión sobre la naturaleza jurídica de la nueva legítima vasca, puede encontrarse en la obra de Gorka Horacio Galicia-AizPurua, La nueva legítima vasca (Ley 5/2015, de 25 de junio, de derecho civil vasco), 4 Actualidad Jurídica Iberoamericana, 303-320 (2016). Disponible en: http://roderic.uv.es/handle/10550/52729. En este artículo, el autor se decanta por considerar esta institución como una pars bonorum, pues en su parecer no se dan todas las condiciones necesarias para verla como una pars valoris.

80 Artículo 51.1 LDCV: El causante podrá disponer de la legítima a favor de sus nietos o descendientes posteriores, aunque vivan los padres o ascendientes de aquellos.

81 Artículo 54 LDCV: El cónyuge viudo o miembro superviviente de la pareja de hecho, además de su 
Respecto a las parejas de hecho, debe destacarse el contenido de la Sentencia del Tribunal Constitucional (en adelante, TC), 93/2013, de 23 de mayo, que sustancia el recurso de inconstitucionalidad interpuesto contra la Ley Foral navarra 6/2000, de 3 de julio, para la igualdad jurídica de las parejas de hecho. En esa sentencia, el TC, al razonar sobre la extensión del principio de libre desarrollo de la personalidad, llega a la conclusión de que para aplicar derechos a las parejas de hecho, estos deben ser asumidos y consentidos expresamente por los miembros de la misma, aunque estos sean reconocidos genéricamente por la legislación, como ocurre en este caso. Esta sentencia ha despertado críticas por parte de la doctrina, al considerar que "semejante protección reforzada de la voluntad, que en realidad supone requerir una suerte de doble consentimiento, no puede resultar desde luego exigencia del libre desarrollo de la personalidad" 82 .

\section{B. Primera excepción del régimen vasco: el fuero de Bizkaia}

Una vez expuestos los rasgos fundamentales del régimen general, es el momento de hacer referencia a los dos regímenes especiales enunciados anteriormente. En primer lugar, se analizará el régimen previsto en el Fuero de Bizkaia, regulado en los artículos 61 a 87 LDCV que, como se anunció, destaca un elemento fundamental, el de la troncalidad. La troncalidad hace referencia a la obligación de que los bienes inmuebles raíces ${ }^{83}$, que estén en el territorio de aplicación del Fuero ${ }^{84}$, deban ser heredados por las parientes tron-

legítima, tendrá un derecho de habitación en la vivienda conyugal o de la pareja de hecho, mientras se mantenga en estado de viudedad, no haga vida marital ni tenga un hijo no matrimonial o no constituya una nueva pareja de hecho.

82 Clara Isabel Asua-GonzÁlez, La STC 93/2013, de 23 de mayo, y la regulación del régimen interno de las convivencias no matrimoniales en la comunidad autónoma del País Vasco, 103 Revista Vasca de Administración Pública, RVAP, 17-54, 28-32 (2015). Disponible en: https://goo.gl/mKgsif

83 Son considerados bienes inmuebles raíces, según el artículo 64 LDCV: 1. A efectos de troncalidad son bienes raíces la propiedad y demás derechos reales de disfrute que recaigan sobre el suelo y todo lo que sobre este se edifica, planta y siembra. 2. Los bienes muebles destinados o unidos a los expresados en el párrafo anterior tendrán la consideración de raíces, salvo que, pudiendo ser separados sin detrimento, se transmitan con independencia. 3. No están sujetos al principio de troncalidad los frutos pendientes y las plantas, cuando sean objeto de transmisión separada del suelo, ni los árboles, cuando se enajenen para su tala.

84 Artículo 61.2 LDCV: Se entiende por infanzonado o tierra llana todo el territorio histórico de Bizkaia, con excepción de la parte no aforada del territorio de las villas de Balmaseda, Bermeo, Bilbao, 
queros. Según el artículo 66 LDCV, se pueden distinguir tres tipos de parientes tronqueros; así, en la línea recta descendente, los hijos y demás descendientes, en la línea recta ascendente, los ascendientes por la línea de donde proceda el bien raíz, cualquiera que sea el título de adquisición, y en la línea colateral, los parientes colaterales dentro del cuarto grado por la línea de donde procede el bien raíz. Respecto de los bienes raíces adquiridos por los cónyuges durante la vigencia de un matrimonio, o por los miembros de una pareja de hecho durante la vigencia de la misma, ambos cónyuges o miembros de la pareja de hecho son tronqueros. Aunque estos bienes se transmitan a los hijos o descendientes, los cónyuges o miembros de la pareja de hecho adquirentes siguen siendo tronqueros de la línea ascendente, cualquiera que sea el grado de parentesco con el descendiente titular ${ }^{85}$. En último lugar, en relación con las líneas, el pariente más próximo excluye al más remoto.

En último lugar, se debe poner de manifiesto la posibilidad de constituir el denominado usufructo poderoso ${ }^{86}$, en el cual el elemento de la troncalidad interacciona con los derechos de los legitimarios y estas relaciones contienen unas reglas de juego, concretamente en el artículo 70 LDCV. En síntesis, se debe resaltar que los derechos de troncalidad prevalecen sobre la legítima y que, cuando en una persona concurra la doble condición de sucesor tronquero y legitimario, los bienes que le correspondan como tronquero se imputarán a su legítima. Además, los bienes troncales del causante se computarán para el cálculo de la cuota de legítima, y se entenderán imputados en primer lugar al pago de la misma, salvo disposición expresa en contrario del testador. En relación con el cónyuge viudo, se debe resaltar que, su legítima deberá ser pagada con bienes no troncales, y solamente cuando estos no existan, podrá acudirse a los troncales en la cuantía que sea necesaria y, que en ningún caso los derechos troncales pueden afectar los derechos reconocidos al cónyuge viudo o al miembro superviviente de la pareja de hecho, ni

Durango, Ermua, Gernika-Lumo, Lanestosa, Lekeitio, Markina-Xemein, Ondarroa, Otxandio, Portugalete, Plentzia y la ciudad de Orduña.

85 Ahora bien, hay límites a la extensión de la troncalidad, descritos en el artículo 67 LDCV: Así, en la línea descendente, el parentesco troncal se prolonga sin limitación de grado, en la ascendente, termina en el ascendiente que primero poseyó el bien raíz y, en la colateral, llega hasta el cuarto grado civil, incluso, de parentesco.

86 Artículo 92 LDCV: El usufructo poderoso es un derecho personalísimo. No podrá ser enajenado ni gravado por ningún título, salvo autorización del constituyente. 
el legado de usufructo universal a favor del mismo. Salvadas estas especialidades, será de aplicación el resto de normas descritas en el régimen general.

\section{Segunda excepción del régimen vasco: el fuero de Ayala}

El segundo régimen especial es el del Fuero de Ayala, donde impera la libertad absoluta de testar, libertad de la que han dispuesto los habitantes del valle de Ayala ${ }^{87}$ desde 1373, cuando se promulgó su Fuero, formado por 95 capítulos; esta libertad de testar se recoge expresamente con la siguiente fórmula, Otrosí todo hombre o mujer estando en su sana memoria pueda mandar lo suio ó parte dello á quienquisiera por Dios, é por su alma ó por servicio que le fizo ${ }^{88}$.

Este régimen está regulado en los artículos 88 a 95 del Código Civil vasco. La piedra angular del sistema es la proclamación de la absoluta libertad de testar, contenida en el artículo 89 LDCV, expresada en los siguientes términos "los que ostenten la vecindad civil local ayalesa pueden disponer libremente de sus bienes como quisieren y por bien tuvieren por testamento, donación o pacto sucesorio, a título universal o singular, apartando a sus legitimarios con poco o mucho". En el caso de que no se incluya a alguno de los herederos en el testamento, se producirá un apartamiento del mismo, expreso en la totalidad o parte de los bienes del disponente, constituido a favor tanto de familiares como de extraños, realizado tanto por actos inter vivos o mortis causa. Si el usufructuario poderoso dispone parcialmente de los bienes, los legitimarios favorecidos quedan apartados con los bienes recibidos, sin perjuicio de que, en actos posteriores, pueda el usufructuario favorecerles con otros bienes.

87 El ámbito de aplicación territorial del régimen está en el artículo 88 LDCV: El Derecho civil propio del valle de Ayala rige en los términos municipales de Ayala, Amurrio y Okondo, y en los poblados de Mendieta, Retes de Tudela, Santacoloma y Sojoguti del municipio de Artziniega.

88 Véase un estudio más profundo sobre los orígenes del fuero en la obra de Víctor Angoitia-GorosTIAGA, El usufructo poderoso del fuero de Ayala, 27 (Diputación Foral de Álava, Vitoria-Gasteiz, 1999). 


\section{CONCLUSIONES}

La legítima es sin lugar a dudas uno de los principales caballos de batalla de la disciplina del derecho de sucesiones e, incluso, del derecho civil en general. Desde sus orígenes, desde el derecho romano, hasta la actualidad, se ha configurado como un límite que actúa sobre la libertad del testador para distribuir sus bienes en función de sus preferencias, salvo, como se ha expuesto, en el régimen foral de las Islas Baleares, donde la legítima se configuraba desde un punto de vista positivo, es decir, el derecho que tiene una serie de sujetos, denominados legitimarios, para obtener una porción de bienes del caudal hereditario, o bien, una determinada cuota.

En relación con las injustas diferencias expuestas en los regímenes existentes en el territorio español, en el sistema de derecho común, el Código Civil español establece que ostentan la condición de legitimario, tres sujetos distintos: los hijos y descendientes, los padres y ascendientes, y el cónyuge viudo. En el presente estudio, ha quedado demostrado que es difícil encontrar cualquier igualdad entre los regímenes forales y el sistema común, de suerte tal que, al analizar en primer lugar la figura de los ascendientes, se observa que ni en Galicia, Navarra, Aragón y el régimen general del País Vasco, ostentan esta condición y, en el caso catalán, solo la ostentarán en el caso de que no existan descendientes. En relación con la figura del cónyuge viudo, también se puede observar, como en la mayoría de ocasiones, no tiene la consideración de heredero forzoso, pero en diversos regímenes forales, se articulan diversas medidas para intentar salvaguardar sus intereses, por ejemplo, destaca el caso catalán con el establecimiento de la ya explicada, cuarta viudal.

La condición de legitimario no es solo la única diferencia encontrada en el análisis efectuado en el presente trabajo, sino que hay otra gran diferencia: la relativa a la cuota legitimaria. En el derecho común, a los descendientes les corresponden las dos terceras partes del haber hereditario; a los ascendientes, en cambio, la mitad del haber hereditario de los hijos y descendientes salvo en el caso en que concurrieren con el cónyuge viudo del descendiente causante, en cuyo supuesto será de una tercera parte de la herencia y, al cónyuge viudo se le reconoce un derecho real de usufructo cuya extensión dependerá de los sujetos con quienes concurra a la sucesión. Pues 
bien, en los regímenes forales analizados, estas cuotas legitimarias están alteradas, ya que estos territorios, haciendo uso de las competencias en materia de derecho civil que tienen atribuidas, han decidido, a veces por razones históricas, y otras por razones prácticas, modificarlas. Solo a modo de ejemplo, y teniendo en cuenta la cuota del sujeto que siempre está recogido como legitimario, se puede observar que en ningún régimen foral, esta legítima tiene una cuota tan alta, así en Galicia y Cataluña solo tienen derecho a una cuarta parte del haber hereditario por ejemplo, a la mitad en Aragón, a un tercio en el régimen general del País Vasco, a la mitad o un tercio, dependiendo de con qué sujetos concurran en las Islas Baleares y, como caso más paradigmático, e incluso deprimente desde el punto de vista del interés del descendiente, a cinco sueldos febles o carlines en Aragón.

En último lugar, no sería adecuado terminar el presente trabajo, sin dedicar unas breves líneas a la discusión acerca de la institución analizada. Efectivamente, la legítima, cómo no, es una restricción importante en la libertad del testador, restricción que, tiene un fin último: la supervivencia de la familia y, fundamental, como se ha expuesto en el trabajo, de los hijos y descendientes. Realmente, muchas voces - la mayoría de importancia manifiesta - critican la permanencia en pleno siglo XXI de la figura, pero, desde el punto de vista de quien escribe estas líneas, la legítima es una institución acertada, ya que su fin último es garantizar la estabilidad de lo más importante de la vida de un ser humano, aunque a veces no se dé cuenta de ello, su familia. Dicho lo anterior, es menester exponer la necesidad de una reforma en el derecho común de la figura, reforma que pasa necesariamente por rebajar la cuota legitimaria de los descendientes, eliminar a los ascendientes como herederos forzosos, eso sí, introduciendo como ocurre en los regímenes forales, un derecho de alimentos en los casos de necesidad para los mismos, y por qué no, garantizar una uniformidad en los derechos sucesorios tanto del testador como de los herederos forzosos en todo el territorio español, ya que el sistema actual brilla por la desigualdad — una nota fundamental y a veces sin justificación histórica- entre las regiones. 


\section{BIBLIOGRAFÍA}

\section{Libros}

Acedo-Penco, Ángel, Derecho de sucesiones. El testamento y la herencia (Editorial Dykinson, Madrid, 2014).

Albaladejo-García, Manuel, Derecho Civil, I, Introducción y parte general (17 ${ }^{\mathrm{a}} \mathrm{ed}$., Editorial Edisofer, Madrid, 2006).

Angoitia-Gorostiaga, Víctor, El usufructo poderoso del fuero de Ayala (Diputación Foral de Álava, Vitoria-Gasteiz, 1999).

Lacruz-Berdejo, José Luis, Elementos de derecho civil, V, Sucesiones (Editorial Dykinson, Madrid, 2009).

Lasarte-Álvarez, Carlos, Principios de derecho civil VII, Derecho de sucesiones (10 ed., Editorial Marcial Pons, Madrid, 2015).

Pablo-Contreras, Pedro de; Pérez-Álvvarez, Miguel Ángel; Martínez de AguirreAldaz, Carlos \& Cámara-Lapuente, Sergio, Curso de Derecho civil V, Derecho de Sucesiones (Editorial Colex, Madrid, 2013).

Pous de la Flor, María Paz, Partición de la herencia (Editorial Juruá, Lisboa, 2016).

Rivas-Martínez, Juan José, Derecho de sucesiones. Común y foral, Tomo II (4ª ed., Editorial Dykinson, Madrid, 2009).

Roca-Sastre, Ramón María, Estudios sobre sucesiones (Editorial Instituto de España, Madrid, 1981).

Román-García, Antonio, Derecho de sucesiones, instituciones de derecho civil español VII (Editorial McGraw-Hill, Madrid, 1999).

\section{Contribución en obra colectiva}

Espinosa de Soto, José L., Capítulo $V$, de las legítimas, en Derecho de sucesiones y régimen económico familiar de Galicia. Comentarios a los Títulos IX y X y a la disposición adicional tercera de la Ley 2/2006, de 14 de junio y a la Ley 10/2007, de 28 de junio, volumen II, 1550-1630 (Juan M. Cora-Guerreiro, Francisco M. Ordóñez-Armán \& Víctor J. Peón-Rama, coords., Colegio Notarial de Galicia, Madrid, 2007).

Galicia-Aizpurua, Gorka Horacio, Legítimas y libertad de testar en el País Vasco, en Tratado de legítimas, 417-470 (TeOdora FeliPA Torres-García, coord., Editorial Atelier, Barcelona, 2012).

García-Rubio, María Paz; Nieto-Alonso, Antonia \& Herrero-Oviedo, Margarita, Las legítimas en la Ley 2/2006 de Derecho civil de Galicia, en Tratado de legítimas, 203-290 (Teodora Felipa Torres-García, coord., Editorial Atelier, Barcelona, 2012).

Parra-Lucán, María Ángeles, La viudedad, en Tratado de derecho de sucesiones: código civil y normativa civil autonómica: Aragón, Baleares, Cataluña, Galicia, Navarra, 
País Vasco, 2100-2270 (María del Carmen Gete-Alonso y Calera, Editorial Thomson Reuters, Navarra, 2011).

Parra-Lucán, María Ángeles \& Barrio-Gallardo, Aurelio, La legítima en derecho aragonés, en Tratado de legítimas, 359-416 (Teodora Felipa Torres-García, coord., Editorial Atelier, Barcelona, 2012).

Ribot-Igualada, Jordi, Comentario al art. 451-17 CC Cat, en Comentari al llibre quart del Codi civil de Catalunya, relatiu a les successions, II, X-X, 1393-1418 (JOAN EGEAI-FernÀndeZ \& JoSEP Ferrer-RibA, dirs., Editorial Atelier, Barcelona, 2009).

Serrano-García, José Antonio, La legítima en Aragón, en Tratado de derecho de sucesiones: código civil y normativa civil autonómica: Aragón, Baleares, Cataluña, Galicia, Navarra, País Vasco, 1850-1945 (María del Carmen Gete-Alonso y CALERA, Editorial Thomson Reuters, Navarra, 2011).

Vaquer-Aloy, Antoni, Freedom of Testation, Compulsory Share and Disinheritance Based on Lack of Family Relationship, en The Law of Succession: Testamentary Freedom. European Perspectives, 89-104 (Miriam Anderson \& Esther Arroyo I Amayuelas, eds., Editorial Europa Law Publishing, Groningen, 2007).

Vaquer-Aloy, Antoni, La legítima en el Derecho civil de Cataluña, en Tratado de Legítimas, 471-515 (Teodora Felipa Torres-García, coord., Editorial Atelier, Barcelona, 2012).

Vila-Ribas, María del Carmen; Ferrer-Vanrell, María Pilar \& Munar-Bernat, Pedro A., La legítima en el derecho civil de las Islas Baleares, en Tratado de legítimas, 291-358 (Teodora Felipa Torres-García, coord., Editorial Atelier, Barcelona, 2012).

\section{Revistas}

Acedo-Penco, Ángel, Derecho civil autonómico versus derecho civil estatal: estado de la cuestión tras la sentencia del Tribunal Constitucional 31/2010 de 28 de junio, 38 Anuario de la Facultad de Derecho, 245-259 (2010). Disponible en: https://dialnet. unirioja.es/servlet/articulo?codigo $=3434370$, https://goo.gl/GosplR

Aguilar-Díaz, Richard, De la libertad para testar con la legítima, 6 La Ley Derecho de Familia: Revista Jurídica sobre Familia y Menores, 75-84 (2015).

Arechederra-Aranzadi, Luis Ignacio, Competencia en materia de derecho civil, Diario La Ley, 950-1110 (1986).

Arroyo i Amayuelas, Esther \& Farnós-Amorós, Esther, Entre el testador abandonado y el legitimario desheredado ¿̨a quién prefieren los tribunales?, 2 InDret, 1-32 (2015). Disponible en: http://www.indret.com/pdf/1132_es.pdf

Asua-GonzÁlez, Clara Isabel, La STC 93/2013, de 23 de mayo, y la regulación del régimen interno de las convivencias no matrimoniales en la comunidad autónoma del País Vasco, 103 Revista Vasca de Administración Pública, RVAP, 17-54 (2015). Disponible en: https://goo.gl/mKgsif

Barrio-Gallardo, Aurelio, Atemperar la rigidez de la legítima, 21 Revista Doctrinal Aranzadi Civil-Mercantil, 1-25 (2007). 
Barrio-Gallardo, Aurelio, Estudio histórico-comparado de la libertad de testar en Inglaterra y Aragón, XVII Revista de Derecho Civil Aragonés, RDCA, 45-92 (2011). Disponible en: http://ifc.dpz.es/recursos/publicaciones/32/29/02barrio.pdf

Bermejo-Pumar, María Mercedes, El sistema legitimario en la Ley 2/2006, de 14 de junio, de derecho civil de Galicia (primera parte), 65 Revista Jurídica del Notariado, $R J N, 9-128$ (2008). Disponible en: https://goo.gl/tWUfe8

Botana-García, Gema Alejandra, Preterición, 15 Actualidad Civil, Sección Estudios de Jurisprudencia, 1821-1844 (2004).

Busto-Lago, José Manuel, Elementos para una interpretación no perturbadora de la equiparación al matrimonio de las relaciones more uxorio realizada por la Disposición Adicional Tercera de la LDCG 2006, 726 Actualidad Jurídica Aranzadi, 1-19 (2007).

Carballo-Fidalgo, Marta, La legítima en la ley de derecho civil de Galicia, Actualidad Civil, 1553-1578 (2001).

CASTÁN-VÁzQuez, José María, Notas sobre la sucesión contractual en el derecho español, 17 Anuario de Derecho Civil, 2, 367-382 (1964). Disponible en: https://www.boe.es/ publicaciones/anuarios_derecho/abrir_pdf.php?id=ANU-C-1964-20036700382

CAstellanos-Ruiz, EsPeranza, Reenvio, unidad de la sucesión y armonía internacional de soluciones en el derecho sucesorio, 2 International Law: Revista Colombiana de Derecho Internacional, 211-260 (2003). Disponible en: http://www.redalyc.org/ articulo.oa?id=82400206

Celaya-Ibarra, Adrián, Nuestra libertad de testar, 8 Jado: Boletín de la Academia Vasca de Derecho $=$ Zuzenbidearen Euskal Akademiaren Aldizkaria, 19, 7-16 (2010). Disponible en: https://dialnet.unirioja.es/servlet/articulo?codigo $=3329486$

Cereceda-Marquínez, Joaquín, Ley de sucesiones, Título VI, De la legítima, 5 Revista de Derecho Civil Aragonés, RDCA, 1, 111-122 (1999).

Díez-Ballesteros, Juan Alberto, La separación y sus consecuencias sobre la legítima del cónyuge viudo. Comentario de la resolución de la Dirección General de los Registros y del Notariado de 25 de junio de 1997, La Ley: Revista jurídica española de doctrina, jurisprudencia y bibliografía, 1757-1766, (1999).

Fernández GonzÁlez-Regueral, María Ángeles, Separación conyugal: la legítima del cónyuge viudo, La Ley: Revista jurídica española de doctrina, jurisprudencia y bibliografía, 2084-2091, (1997).

Galicia-Aizpurua, Gorka Horacio, La nueva legítima vasca (Ley 5/2015, de 25 de junio, de derecho civil vasco), 4 Actualidad Jurídica Iberoamericana, 303-320 (2016). Disponible en: http://roderic.uv.es/handle/10550/52729

García-Presa, Inmaculada, Visión comparativa del derecho de sucesiones entre la normativa gallega y la estatal, 3 Actualidad Civil, 276-299 (2013).

García-Rubio, María Paz, Las parejas de hecho en el derecho civil gallego o cómo la corrección política da palos de ciego, 16 Revista Xurídica da Universidade de Santiago de Compostela, 1, 187-208 (2007). Disponible en: http://dspace.usc.es/ handle/10347/7872

García-Valdecasas, Guillermo, La legítima como cuota hereditaria y como cuota de 
valor, XLVII Revista de Derecho Privado, 957-977 (1963).

Grimalt-Servera, Pedro, Los derechos legitimarios y legítimos del cónyuge viudo separado en el Código Civil español y en la compilación del derecho civil de las Islas Baleares, 3 Actualidad Jurídica Iberoamericana, 565-576 (2015). Disponible en: http://roderic.uv.es/handle/10550/47085

Lacruz-Berdejo, José Luis, Las legítimas en la compilación, XLIV Revista Crítica de Derecho Inmobiliario, 505-540 (1968). Disponible en: http://goo.gl/VI9ITk

Manzano-Fernández, María del Mar, Preguntas y respuestas sobre el artículo 857 del Código Civil. La legítima del descendiente del desheredado, 10 Actualidad Civil, 44-55 (2015). Disponible en: http://goo.gl/vb0of0

Martínez-Martínez, María, Sucesión legal y usufructo viudal de cónyuge separado de hecho (Comentario a la Sentencia del Tribunal Superior de Justicia de Aragón de 25 de junio de 2007), 2 Revista de Derecho Civil Aragonés, RDCA, 193-218 (2008). Disponible en: http://derecho-aragones.net/cuadernos/document.php?id=459

O'CAllaghan-Muñoz, Xavier, A vueltas con la desheredación y a revueltas con la legítima, 5 Actualidad Civil, 4-7 (2015). Disponible en: https://goo.gl/1kyuU6

Pardo-Gato, José Ricardo, Recensión: Galicia y su derecho privado, de Ramón P. Rodríguez-Montero, 36 Revista Jurídica de Asturias, 271-279 (2013). Disponible en: http://goo.gl/O35kJY

Peña-Bernaldo de Quirós, Manuel, La naturaleza de la legítima, 38 Anuario de Derecho Civil, 4, 849-908 (1985). Disponible en: https://www.boe.es/publicaciones/ anuarios_derecho/abrir_pdf.php?id=ANU-C-1986-20057100580_ANUARIO_ DE_DERECHO_CIVIL_La_naturaleza_de_la_leg\%EDtima

Rico-Sandoval, Ronald Zuleyman, Para una crítica de la violencia del derecho civil, 120 Vniversitas, 169-200 (2010). Disponible en: http://revistas.javeriana.edu.co/ index.php/vnijuri/article/view/14455/11652

Romero-Coloma, Aurelia María, Usufructo universal del cónyuge viudo: su problemática jurídica, XXXIII Diario La Ley, 7840, 1-12 (2012). Disponible en: http:// mjavierjm-niharra.blogspot.com.es/2012/05/usufructo-universal-del-conyugeviudo.html

Serrano-García, José Antonio, La legítima en Aragón, XVI Revista de Derecho Civil Aragonés, RDCA, 67-134 (2010). Disponible en: http://ifc.dpz.es/recursos/ publicaciones/30/96/02serrano.pdf, http://goo.gl/Rf44ok

Vallet de Goytisolo, Juan B., Notas críticas acerca de la pretendida distinción entre cuota de reserva y cuota de legítima, 18 Anuario de Derecho Civil, 1, 3-140 (1965). Disponible en: https://www.boe.es/publicaciones/anuarios_derecho/abrir_pdf. php?id=ANU-C-1965-10000300140

VAQUer-Aloy, Antoni, Reflexiones sobre una eventual reforma de la legítima, 3 InDret, 1-25 (julio de 2007). Disponible en: http://www.indret.com/es/?ed=32, http:// www.indret.com/pdf/457_es.pdf 


\section{Normativa española y autonómica}

España, Constitución Española, 311 Boletín Oficial del Estado, BOE, 29 de diciembre de 1978. Disponible en: https://www.boe.es/buscar/act.php?id=BOE-A-1978-31229

España, Decreto Legislativo 79/1990, de 6 de septiembre, por el que se aprueba el texto refundido de la compilación del derecho civil de las Islas Baleares, 120 Boletín Oficial del Estado, BOE, 2 de octubre de 1990. Disponible en: https://www.boe. es/buscar/doc.php?id=BOIB-i-1990-90001

España, Decreto Legislativo 1/2011, de 22 de marzo, del Gobierno de Aragón, por el que se aprueba, con el título de Código del Derecho Foral de Aragón, el texto refundido de las leyes civiles aragonesas, 67 Boletín Oficial del Estado, BOE, 29 de marzo de 2011. Disponible en: https://www.boe.es/buscar/doc. php?id=BOA-d-2011-90007,

España, Ley 5/1961, de 19 de abril, por la que se aprueba la compilación del derecho civil especial de las Islas Baleares, 95 Boletín Oficial del Estado, BOE, 21 de abril de 1961. Disponible en: https://www.boe.es/diario_boe/txt.php?id=BOE-A-1961-7734

España, Ley 1/1973, de 1 de marzo, por la que se aprueba la Compilación del Derecho Civil Foral de Navarra, 57 Boletín Oficial del Estado, BOE, 7 de marzo de 1973. Disponible en: https://www.boe.es/buscar/doc.php?id=BOE-A-1973-330, https:// www.boe.es/diario_boe/txt.php?id=BOE-A-1987-13331

España, Ley 3/1992, de 1 de julio, del Derecho Civil Foral del País Vasco, 39 Boletín Oficial del Estado, BOE, 15 de febrero de 2012. Disponible en: https://www.boe. es/diario_boe/txt.php?id=BOE-A-2012-2257

España, Ley 4/1995, de 24 de mayo, de derecho civil de Galicia, 152 Boletín Oficial del Estado, BOE, 27 de junio de 1995. Disponible en: https://www.boe.es/diario_boe/ txt.php?id=BOE-A-1995-15453

España, Ley 1/1999, de 24 de febrero, de sucesiones por causa de muerte, 72 Boletín Oficial del Estado, BOE, 25 de marzo de 1999. Disponible en: https://www.boe. es/boe/dias/1999/03/25/pdfs/A11723-11750.pdf

España, Ley 2/2006, de 14 de junio, de derecho civil de Galicia, 191 Boletín Oficial del Estado, BOE, 11 de agosto de 2006. Disponible en: https://www.boe.es/buscar/ act.php?id=BOE-A-2006-14563

España, Ley 10/2008, de 10 de julio, del libro cuarto del Código Civil de Cataluña, relativo a las sucesiones, 190 Boletín Oficial del Estado, BOE, 7 de agosto de 2008. Disponible en: https://www.boe.es/diario_boe/txt.php?id=BOE-A-2008-13533

España, Ley 5/2015, de 25 de junio, de derecho civil vasco, 176 Boletín Oficial del Estado, BOE, 24 de julio de 2015. Disponible en: https://www.boe.es/diario_boe/txt. php?id=BOE-A-2015-8273

España, Real Decreto de 24 de julio de 1889 por el que se publica el Código Civil, 206 Boletín Oficial del Estado, BOE, 25 de julio de 1889. Disponible en: https://www. boe.es/buscar/act.php?id=BOE-A-1889-4763 


\section{Jurisprudencia española}

España, Audiencia Provincial de Castellón, Sentencia, 27 de octubre de 2004, magistrado ponente David Gericó-Sobrevela. Disponible en: http://goo.gl/qRN2Bj

España, Audiencia Provincial de Palencia, Sentencia, 4 de noviembre de 2005, magistrado ponente Carlos Javier Álvarez-Fernández. Disponible en: http:// goo.g1/TcGvq3

España, Tribunal Constitucional, Sentencia 93/2013, 23 de mayo, magistrada ponente Adela Asua-Batarrita. Disponible en: https://www.boe.es/diario_boe/txt. php?id=BOE-A-2013-5436

España, Tribunal Supremo de Justicia, Sala Civil, Sentencia, 8 de marzo de 1989, magistrado ponente José Luis Albácar-López. Disponible en: http://supremo. vlex.es/vid/-76213414

España, Tribunal Supremo de Justicia, Sala Civil, Sentencia, 26 de abril de 1997, magistrado ponente Pedro González-Poveda. Disponible en: http://goo.gl/ AtLdWn

España, Tribunal Supremo de Justicia, Sala Civil, Sentencia, 3 de junio de 2014, magistrado ponente Francisco Javier Orduña-Moreno. Disponible en: http:// goo.gl/LCt $25 \mathrm{~N}$ 
